\title{
Effects of Exogenous Androgens on Platelet Activity and Their Thrombogenic Potential in Supraphysiological Administration: A Literature Review
}

\author{
Adrian Eugen Roşca ${ }^{1,2,3, *}$, Ana-Maria Vlădăreanu ${ }^{4, *}$, Alina Mititelu ${ }^{4}$, Bogdan Ovidiu Popescu 2,5, \\ Corin Badiu ${ }^{6} \mathbb{1}$, Constantin Căruntu ${ }^{7,8} \mathbb{1}$, Suzana Elena Voiculescu ${ }^{1}$, Minodora Onisâi ${ }^{4} \mathbb{D}$, Şerban Gologan ${ }^{9}$, \\ Radu Mirica ${ }^{10}$ and Leon Zăgrean ${ }^{1}$
}

check for

updates

Citation: Roşca, A.E.; Vlădăreanu,

A.-M.; Mititelu, A.; Popescu, B.O.; Badiu, C.; Căruntu, C.; Voiculescu, S.E.; Onisâi, M.; Gologan, Ş.; Mirica, R.; et al. Effects of Exogenous Androgens on Platelet Activity and Their Thrombogenic Potential in Supraphysiological Administration A Literature Review. J. Clin. Med. 2021, 10, 147. https://doi.org/ 10.3390/ jcm10010147

Received: 19 November 2020 Accepted: 28 December 2020 Published: 4 January 2021

Publisher's Note: MDPI stays neutral with regard to jurisdictional clai$\mathrm{ms}$ in published maps and institutional affiliations.

Copyright: $\odot 2021$ by the authors. Licensee MDPI, Basel, Switzerland. This article is an open access article distributed under the terms and conditions of the Creative Commons Attribution (CC BY) license (https:// creativecommons.org/licenses/by/ $4.0 /)$.
1 Division of Physiology and Neuroscience, Department of Functional Sciences, Carol Davila University of Medicine and Pharmacy, 050474 Bucharest, Romania; suzana.voiculescu@umfcd.ro (S.E.V.); leon.zagrean@umfcd.ro (L.Z.)

2 Victor Babeş National Institute of Research-Development in the Pathology Domain, 050096 Bucharest, Romania; bogdan_ovidiu_popescu@yahoo.com

3 Department of Cardiology, Emergency University Hospital of Bucharest, 050098 Bucharest, Romania

4 Department of Hematology, Carol Davila University of Medicine and Pharmacy, Emergency University Hospital of Bucharest, 050098 Bucharest, Romania; ahmititelu@yahoo.com (A.M.); minodorel@yahoo.com (M.O.)

5 Department of Neurology, Carol Davila University of Medicine and Pharmacy, Colentina Clinical Hospital, 020125 Bucharest, Romania

6 Department of Endocrinology, C.I. Parhon National Institute of Endocrinology, Carol Davila University of Medicine and Pharmacy, 11863 Bucharest, Romania; badicrin@yahoo.co.uk

7 Division of Physiology, Department of Fundamental Disciplines, Carol Davila University of Medicine and Pharmacy, 050474 Bucharest, Romania; costin.caruntu@gmail.com

8 Department of Dermatology, "Prof. N.C. Paulescu" National Institute of Diabetes, Nutrition and Metabolic Diseases, 011233 Bucharest, Romania

9 Department of Gastroenterology, Carol Davila University of Medicine and Pharmacy, Elias Clinical Hospital, 011461 Bucharest, Romania; serbangologan@gmail.com

10 Department of Surgery, Carol Davila University of Medicine and Pharmacy, "Sf. Ioan" Clinical Hospital, 042122 Bucharest, Romania; mirica_rm@yahoo.com

* Correspondence: adrian.rosca@umfcd.ro (A.E.R.); anamaria.vladareanu@umfcd.ro (A.-M.V.)

\begin{abstract}
Anabolic androgenic steroids (AAS), simply called "androgens", represent the most widespread drugs used to enhance performance and appearance in a sporting environment. Highdosage and/or long-term AAS administration has been associated frequently with significant alterations in the cardiovascular system, some of these with severe endpoints. The induction of a prothrombotic state is probably the most life-threatening consequence, suggested by numerous case reports in AAS-abusing athletes, and by a considerable number of human and animal studies assessing the influence of exogenous androgens on hemostasis. Despite over fifty years of research, data regarding the thrombogenic potential of exogenous androgens are still scarce. The main reason is the limited possibility of conducting human prospective studies. However, human observational studies conducted in athletes or patients, in vitro human studies, and animal experiments have pointed out that androgens in supraphysiological doses induce enhanced platelet activity and thrombopoiesis, leading to increased platelet aggregation. If this tendency overlaps previously existing coagulation and/or fibrinolysis dysfunctions, it may lead to a thrombotic diathesis, which could explain the multitude of thromboembolic events reported in the AAS-abusing population. The influence of androgen excess on the platelet activity and fluid-coagulant balance remains a subject of debate, urging for supplementary studies in order to clarify the effects on hemostasis, and to provide new compelling evidence for their claimed thrombogenic potential.
\end{abstract}

Keywords: anabolic androgenic steroids; AAS; androgens; testosterone; hemostasis/haemostasis; platelet activity; platelet reactivity; platelet aggregation; thrombopoiesis; platelet count; prothrombotic state; thrombotic diathesis; thrombosis 


\section{Introduction}

Anabolic androgenic steroids (AAS) are synthetic derivatives of testosterone, primarily designed to have both an enhanced anabolic and a reduced androgenic activity compared to the parent molecule [1,2]. The anabolic effect is based on their ability to stimulate protein synthesis, muscle mass growth and erythropoiesis. Over 100 synthetic substances have been introduced in clinical practice as treatments for various conditions, such as hypogonadism, anemia secondary to bone marrow insufficiency or renal failure, hereditary angioedema, osteoporosis, catabolic states associated with HIV infection, cancer, burns, chronic obstructive pulmonary disease, alcoholic hepatitis, or neuromuscular diseases [3-5].

Their powerful anabolic properties have led to an illicit use, with them being currently abused in high doses by athletes for enhanced performance, or in the bodybuilding community for cosmetic reasons [5-7]. Even if AAS have a strong anabolic activity, that mimics natural steroids, they still possess androgenic activity [8,9] (Table 1). AAS misuse produces both physical and psychological dependence $[6,10,11]$, leading to long-term self-administration in progressively higher doses and stronger drug combinations [10]. Athletes use two or three different substances simultaneously (stacking), with a total dose equivalent of 600-1000 mg testosterone per week, sometimes up to 3000-5000 mg per week. This equals a blood concentration of 10 to 100 times higher than the physiological one [12]. For instance, considering a parenteral dose of testosterone enanthate or cypionate of 150-200 mg every two week in men with hypogonadism [13], the aforementioned abus dose is 6 to 500 times higher than that recommended in testosterone replacement therapy. AAS abuse is widespread and extending, becoming an alarming public health issue $[10,14,15]$.

Table 1. Main characteristics of selected androgens used in diseases and clinical conditions, or abused by athletes (androgenic: anabolic ratio is that according to Kuhn C.M. et al. 2002 [2]).

\begin{tabular}{cccc}
\hline Types of Androgens & Structural Classification & Way of Administration & Androgenic: Anabolic Ratio \\
\hline Stanozol & $17-\alpha$ derivative & Oral, parenteral & $1: 30$ \\
\hline Oxandrolone & $17-\alpha$ derivative & oral & $1: 10$ \\
\hline Nandrolone & $17-\beta$ derivative & parenteral & $1: 10$ \\
\hline Oxymetholone & $17-\alpha$ derivative & oral & $1: 9$ \\
\hline Methandrostenolone & $17-\alpha$ derivative & oral & $1: 5 \rightarrow 1: 2$ \\
\hline Methyltestosterone & $17-\alpha$ derivative & oral & 1 \\
\hline Testosterone & & & 1 \\
\hline
\end{tabular}

The negative impact of AAS excess is a consequence of their numerous side effects, including endocrine dysfunctions, alterations of the cardiovascular system, liver toxicity, behavioral changes and even psychiatric disorders, some of them with severe endpoints $[10,12,14-17]$. The negative effects on the cardiovascular function have classically been divided into four categories: thrombotic, atherogenic, vasospastic, and cardiomyocyte direct toxicity [18]. AAS-induced cardiovascular events are mostly present in a young and healthy population, with no associated risk factors or proven atherosclerotic lesions [19-24]. This suggests that the pathophysiological mechanism might be atherothrombotic rather than atherogenic, or vasospastic. This conclusion seems more logical in the attempt to explain the basis for the severe adverse effects of androgens misuse $[22,25,26]$.

This review covers the available literature data regarding the influence of androgens usage on platelet function and thrombopoiesis, focusing on their thrombogenic potential in supraphysiological administration, probably the most important cardiovascular side effect emerging from AAS abuse.

\section{Overview of Thrombogenic Potential of Exogenous Androgens}

The thrombogenic potential of androgens has become a matter of high interest as AAS abuse in the sports environment has led to an alarming rate of severe cardiovascular 
events $[10,27,28]$. A considerable number of case reports has been gathered up to date, beginning with the report of McNutt et al. (1988), who noted a myocardial infarction in a weightlifter following AAS abuse [20]. These depict a comprehensive picture of the thromboembolic potential of AAS in high dosages and/or long-term administration. The nonmedical use of these doping substances has been linked to coronary heart disease and myocardial infarction [22,29-50], intra-ventricular thrombosis [23,32,51], cerebrovascular events [38,52-61], peripheral arterial and deep venous thrombosis [51,55,62-67], pulmonary embolism [65-68], retinal vein branch occlusion [69], superior sagittal venous sinus thrombosis [53], abdominal arterial infarction [64], renal infarction [37,70,71], or even sudden death $[19,24,46,72-78]$. Several of the epidemiological studies with a follow-up period of 4 years minimum reported a cardiovascular mortality rate in men exposed to non-therapeutic AAS that was more than double compared to non-users, justifying all the measures taken to decrease AAS misuse among both competitive and amateur athletes [79,80].

The thrombogenic potential of androgens has also been noted in their clinical usage. Cerebral venous thrombosis caused by AAS administration was strongly suggested in a case-report of a 40-year-old woman with aplastic anemia treated with oxymetholone for two years [81]. Male hormones and protein-assimilating hormone therapy in 27 hypoplastic anemia patients resulted in three cases of sagittal sinus thrombosis [82]. A case of acute myocardial infarction was reported in a non-athlete who inadvertently received therapeutic intravenous testosterone for hypogonadism [83,84], as well as a case of stroke secondary to testosterone therapy in a 21-year-old hypogonadal man [84]. A meta-analysis of 27 placebocontrolled studies detected an increased risk of cardiovascular events in men who received testosterone therapy, compared to placebo [85]. A population-based case-control trial has recently reported an increased risk of venous thromboembolism after testosterone therapy, peaking within six months after the treatment cessation [86]. On the other hand, there are data indicating that low serum testosterone concentrations are also associated with increased cardiovascular risk and mortality, and that testosterone replacement therapy may have beneficial effects $[87,88]$. Several recent systematic reviews and meta-analyses did not find clear evidence of increased risk for cardiovascular events in men with testosterone prescription [89,90]. Moreover, low plasma androgen levels in hypogonadal patients have been linked to deficient platelet function, explaining the presence of hemorrhagic diathesis observed in this population [91,92].

Unfortunately, the human data evoking the thrombogenicity of AAS are inconclusive because the findings come mostly from case reports (which generally include a reduced number of individuals), a few epidemiological studies, and a small number of cross-sectional studies. The only appropriate "prospective" studies related to testosteroneinduced thrombogenesis are the experimental ones using animal models of thrombosis, but even those are few. Uzunova et al. performed several in vivo experiments in the 1960-1970s [93-95]. Testosterone cypionate administered in a dose of $10 \mathrm{mg} / \mathrm{kg}$, twice weekly for 2 or 4 weeks, resulted in a reduced obstruction time, increased thrombus weight and high mortality rate in mice, rats or rabbits subjected to occlusive arterial thrombosis, in response to chemical or mechanical stimuli. The administration of flutamide (an androgen receptor blocker), or aspirin (an antiplatelet drug, known as an inhibitor of prostaglandin synthesis), significantly reduced mortality in testosterone-treated animals. The author hypothesized that the thrombotic potential of androgen excess may be related to an increase in endoperoxides and thromboxane generation in platelets [93-95]. Later, Rosenblum et al. (1987) resumed the in vivo experiments of arterial thrombosis, showing a faster onset of aggregation in the mesenteric arterioles of the male mice following the implantation of pellets with either $1.0 \mathrm{mg}$ testosterone or $0.1 \mathrm{mg}$ dihydrotestosterone (DHT) [96]. However, this effect has been considered more likely to be secondary to the endocrine function of the endothelium or adjacent tissue than to the platelet's activity itself. No effect of testosterone or DHT has been observed when the activation of platelet aggregation has been triggered in the mesenteric arterioles of female rats, nor in the pial arterioles of either sex [96]. Inter- 
estingly, at physiological doses, androgens seem to exert the opposite action, inhibiting the induced arterial thrombosis [97].

A high amount of evidence suggests that hemostatic disturbances may lead to cardiovascular disease (CVD), sometimes with severe thrombotic endpoints [98-102]. Direct proofs of androgens' thrombogenic effects are scarce and come from animal models of thrombosis, but there is a considerable amount of indirect data emerging from studies that assess the influence of exogenous androgens on the key processes of hemostasis, such as platelet activation and aggregation (detailed in the following section of this article), or coagulation and fibrinolysis (recently and extensively reviewed) [28,103,104].

The thrombotic risk of supraphysiological androgens may also be indirectly linked to their ability to influence various cardiovascular risk markers. Exogenous androgens in high dosages and/or prolonged administration have been shown to be atherogenic, by inducing ample changes in the lipid profile (increasing low-density lipoprotein-LDL cholesterol, triglycerides and apolipoprotein- $\mathrm{B}$, and decreasing high-density lipoproteinHDL cholesterol and apolipoprotein- $A_{1}$ ) [5,105-109], by increasing plasma homocysteine level [110,111], and by enhancing inflammation and oxidative stress at the endothelial level, with a consecutive reduction in NO synthesis [111-114]. AAS have also been shown to elevate blood pressure $[111,112,115]$ and to induce hemorheological effects, through impairing vascular reactivity $[105,111]$ and triggering a polycythemia-induced hyperviscosity syndrome (an intrinsic anabolic effect) $[16,36,105]$. Since the abovementioned altered parameters have been independently linked to various coagulation abnormalities (they lead to enhanced platelet adhesion and aggregation, activation of the coagulation cascade, and suppression of fibrinolysis [116-127]), it may be assumed that AAS abuse is prone to produce atherothrombotic phenomena also by influencing these cardiovascular risk markers. Moreover, the cardiotoxic effects of extraneous androgens and the structural damage to the heart muscle may lead to intracardiac thrombosis, also reported in athletes abusing AAS. Structural remodeling following myocardial injury, expressed by ventricular hypertrophy and the reparative process of fibrosis, is known to induce functional (electrical) remodeling and diastolic function impairment, thus causing an enhanced risk of arrhythmias onset and predisposing to intracavitary thrombosis occurrence, with subsequent systemic embolism [27,105,128-132].

\section{Overview of Platelet Function}

Platelets are key players in hemostasis and thrombosis, and are a contributing factor in cardiovascular diseases such as heart attacks and strokes. Their activity is related to their capacity to function under proper stimuli. Platelets have four major functions: adherence, activation and secretion, aggregation, and interaction with coagulation factors in order to form the hemostatic plug and maintain hemostasis.

In a fairly simplified view, the hemostatic activity can be considered as a sequence of cellular and molecular events delineated into overlapping phases. It starts with receptorligand bindings, leading to platelet activation through complex mechanisms mediated by intracellular signaling, calcium-dependent cytoskeletal changes, granules release and conformational changes of the fibrinogen (FBG) receptor $\alpha_{\mathrm{IIb}} \beta_{3}$ integrin (aka glycoprotein $\mathrm{IIb} / \mathrm{III}$, GP IIb/IIIa), which supports platelet aggregation [133,134].

Primary platelet adhesion (1) is initiated by the binding of vWF (von Willebrand factor) to a specific glycoprotein (GP) from a circulating platelets' surface, GP $\mathrm{Ib} / \mathrm{IX} / \mathrm{V}$, and also to the subendothelial collagen. This transient "bridge" retains platelets in the injured area and facilitates the contact of other surface GP, GP VI with collagen. This further induces intracellular signaling, leading to platelet activation and the release of secondary platelet agonists, such as thromboxane $\mathrm{A}_{2}\left(\mathrm{TxA}_{2}\right)$ and adenosine diphosphate (ADP), from platelets' dense granules. These soluble agonists, together with locally produced thrombin, contribute to platelet activation trough distinct but interconnected pathways [133]. In addition to its role as a platelet adhesion receptor, GP Ib/IX/V can mediate the intracellular signals, involving the phospholipase $\mathrm{C}$ (PLC) pathway and the $\mathrm{TxA}_{2}$ and ADP pathways, finally leading 
to the activation of integrin $\alpha_{\mathrm{IIb}} \beta_{3}$ [135]. GP VI is the major signaling receptor for collagen on the platelet surface. Platelet activation by GP VI is intermediated by the activation of PLC, ADP release from platelet dense granules (DG) and TxA2 synthesis from arachidonic acid [136]. Platelet activation (2) is a multistep process starting with multiple interconnected platelet receptor-ligand interactions. After adhesion, the soluble agonists thrombin, ADP, $\mathrm{TxA}_{2}$ and epinephrine are the primary drivers for platelet activation. Each of these agonists activates specific $G$ protein-coupled receptors on the platelet surface, triggering intracellular signaling pathways, which is followed by integrin activation and increases in cytosolic $\mathrm{Ca}^{2+}$ (calcium) concentration, with subsequent cytoskeletal reorganization, FBG receptor activation through dimerization (GPIIb/IIIa), and granule secretion [133,137,138].

Phosphoinositide hydrolysis and eicosanoid synthesis pathways are representative of platelet activation.

The phosphoinositide hydrolysis (2a) pathway is initiated when ADP, $\mathrm{TxA}_{2}$ and thrombin bind to specific receptors on platelets' surfaces, such as the following: purinergic receptor $2 \mathrm{Y}_{1}\left(\mathrm{P}_{2} \mathrm{Y}_{1}\right)$ for ADP; TP for TxA 2 ; protease-activated receptor 1 and $4\left(\mathrm{PAR}_{1}\right.$ and $\mathrm{PAR}_{4}$ ) for thrombin. This activates PLC, which hydrolyzes membrane phospholipids to form 1,4,5-inositol trisphosphate ( $\left.\mathrm{IP}_{3}\right)$ and 1,2-diacylglycerol (DAG), which serve as second messengers. $\mathrm{IP}_{3}$ opens the $\mathrm{Ca}^{2+}$ channels in the platelet dense tubular system (DTS), which triggers $\mathrm{Ca}^{2+}$ influx through the plasma membrane. DAG activates protein kinase $\mathrm{C}$ isoforms in the presence of $\mathrm{Ca}^{2+}$, mediating platelet shape changes, platelet granule secretion, and also platelet aggregation $[139,140]$. Thrombin is the most powerful platelet activator, along with collagen. ADP, a weaker agonist, is released by the injured endothelial cells, as well as by DG upon platelet activation. It has two purinergic receptors, $\mathrm{P}_{2} \mathrm{Y}_{1}$ and $\mathrm{P}_{2} \mathrm{Y}_{12}$, both being required for the platelet ADP-induced response [141]. In platelets ADP induces or contributes to: shape change, granule release, $\mathrm{TxA}_{2}$ production, the activation of $\alpha_{\mathrm{IIb}} \beta_{3}$ integrin and subsequent platelet aggregation.

The eicosanoid synthesis pathway $(2 b)$ is initiated by the interaction of $\mathrm{TxA}_{2}$ with its receptor, which activates phospholipase $\mathrm{A}_{2}\left(\mathrm{PLA}_{2}\right) . \mathrm{PLA}_{2}$ is also activated by the rise in cytosolic $\mathrm{Ca}^{2+}$, and is potentiated by GP Ib/IX/V adhesion to collagen through vWF. PLA 2 releases arachidonate from membrane phospholipids, which is converted by cyclooxygenase- 1 to prostaglandins such as $\mathrm{TxA}_{2}[137,140]$. Tx $\mathrm{A}_{2}$ is an important agonist which contributes to the rise in cytosolic $\mathrm{Ca}^{2+}$, the activation of $\alpha_{\mathrm{IIb}} \beta_{3}$ integrin, and granule release. It diffuses across the plasma membrane along with other agonists (ADP) and contributes to the amplification of platelet activation and the recruitment of additional platelets.

The platelet inhibitory pathway (2c) represents a protective, inhibitory mechanism of platelet activation, which occurs via $\mathrm{NO}$ and prostaglandin $\mathrm{I}_{2}\left(\mathrm{PgI}_{2}\right)$. $\mathrm{PgI}_{2}$ stimulates its receptor (IP), inducing a rise in cyclic adenosine monophosphate (cAMP), with subsequent protein kinase A activation via the adenylyl cyclase (AC) pathway. The rising cAMP level leads to impaired phosphoinositide hydrolysis, the attenuation of cytosolic $\mathrm{Ca}^{2+}$ increase in response to agonists, and an accelerated uptake of $\mathrm{Ca}^{2+}$ into DTS. cAMP is an important inhibitor of platelet activation, keeping platelets in a quiescent state in circulation [137]. NO is synthetized by NO synthase (NOS) in the endothelial cells at the site of shear stress, or in the platelets by agonist action (thrombin or ADP) in the presence of increased cytosolic $\mathrm{Ca}^{2+}[142]$. NO induces a rise in cyclic guanosine monophosphate via guanylate cyclase, with subsequent protein kinase $\mathrm{G}$ activation, which decreases the cytosolic $\mathrm{Ca}^{2+}$ by multiple mechanisms, causing the inhibition of platelet activation [142,143].

On this level, ADP through the $\mathrm{P}_{2} \mathrm{Y}_{12}$ receptor and epinephrine through its alpha 2A adrenergic receptor $\left(\alpha_{2} \mathrm{~A}-\mathrm{AR}\right)$ inhibit $\mathrm{AC}$, reducing $\mathrm{NO}$ production and increasing cytosolic calcium, with subsequent stimulatory effects on platelet activation and aggregation. The $\mathrm{P}_{2} \mathrm{Y}_{12}$ receptor is more involved in platelet activation, granule secretion and $\alpha_{\mathrm{IIb}} \beta_{3}$ integrin activation in response to ADP, compared to the $\mathrm{P}_{2} \mathrm{Y}_{1}$ receptor, which has a weaker and more transient effect on platelet aggregation [141]. 
Platelet aggregation (3) represents the process of platelet-platelet cohesion, primarily mediated by the binding of plasma FBG to activated $\alpha_{\mathrm{IIb}} \beta_{3}$ integrin (aka GP IIb/IIIa). Each molecule of FBG binds two adjacent platelets. Following initial platelet adhesion and activation, additional platelets are recruited from the circulation to form a platelet aggregate. Platelet recruitment and $\alpha_{\mathrm{IIb}} \beta_{3}$ integrin-mediated cohesion require platelet activation by $\mathrm{ADP}, \mathrm{TxA}_{2}$ release by platelet $\mathrm{DG}$, and $\mathrm{TxA}_{2}$ generated by the adherent platelets. Thrombin is a constant contributor to platelet activation [140]. The hereafterevolving process is complex, and further requires the tight interaction of platelets with components of the humoral coagulation system, and compounds released from the vessel wall at the site of injury, in order to maintain hemostasis.

The major platelet functions described above are illustrated in Figure 1.

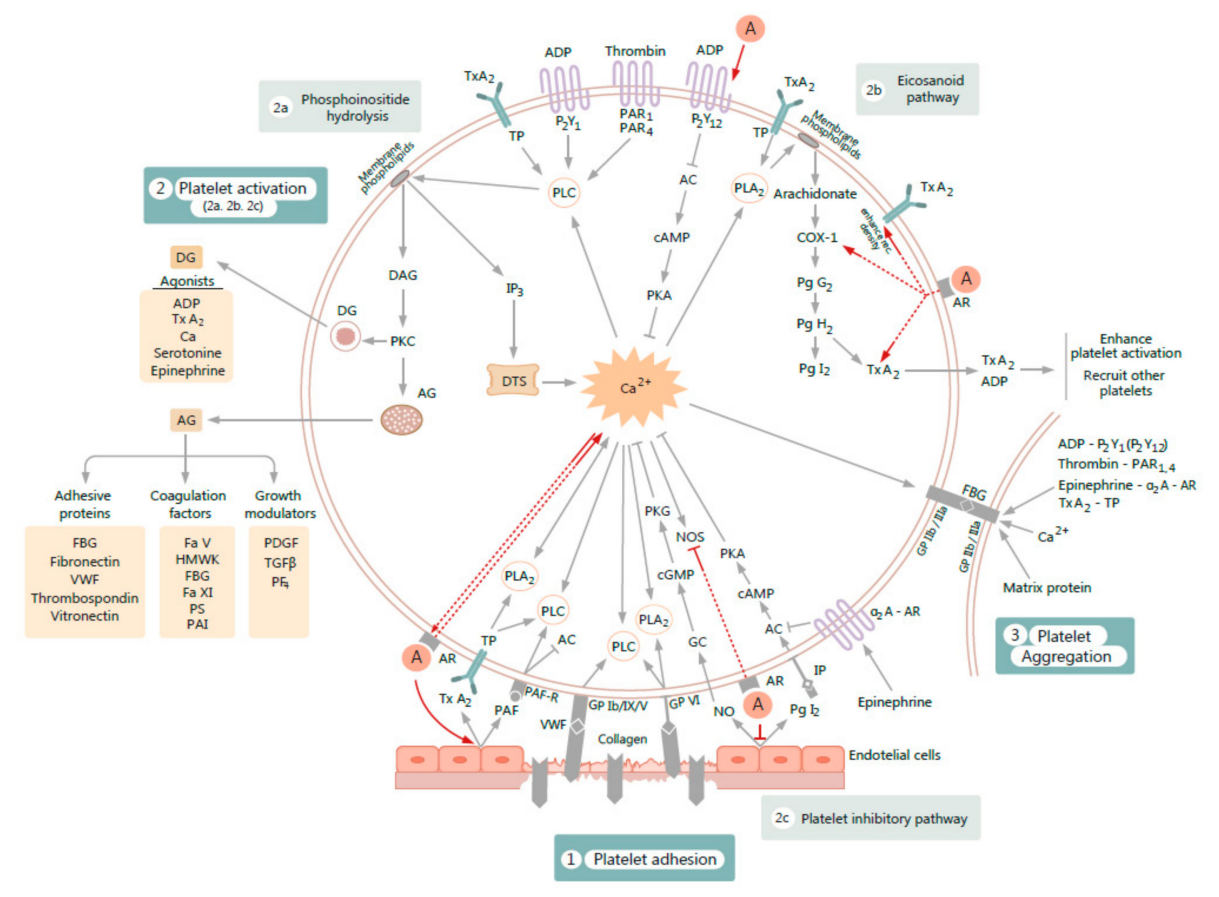

Figure 1. Figure illustrating the influence of exogenous androgens $A$ on various processes involved in platelet activation and subsequent aggregation. The proposed mechanisms of action (figured by red arrows) are as follows: $1 . A$ increase gene expression of purinergic receptor $2 \mathrm{Y}_{12}\left(\mathrm{P}_{2} \mathrm{Y}_{12}\right)$ of adenosine diphosphate (ADP). 2. A enhance cyclooxygenase-1 (COX-1) activity, increase thromboxane $\mathrm{A}_{2}\left(\mathrm{TxA}_{2}\right)$ synthesis, and enhance platelet $\mathrm{Tx} \mathrm{A}_{2}$ receptor (TP) density. 3. By acting on androgen receptor (AR), $A$ enhance platelet free calcium $\left(\mathrm{Ca}^{2+}\right)$. The rise of cytosolic $\mathrm{Ca}^{2+}$ increases AR affinity. 4 . $A$ inhibit cytosolic nitric oxide synthase (NOS) activity and generate complementary processes on endothelium by reducing nitric oxide $(\mathrm{NO})$ release and suppressing prostaglandin $\mathrm{I}_{2}\left(\mathrm{PgI}_{2}\right)$ production. 5. $A$ increase vascular $\mathrm{TxA}_{2}$ receptor density and endothelial $\mathrm{TxA}_{2}$ synthesis. 6 . $A$ increase platelet activator factor (PAF) activity. PAF actions on platelets involves stimulation of phospholipase C (PLC) activity and inhibition of adenylyl cyclase (AC) activity, through which PAF stimulates platelet activation and aggregation. Other abbreviations used: FBG-fibrinogen; VWF-von Willebrand factor; GP-glycoprotein; PLA 2 -phospholipase $\mathrm{A}_{2}$; PAF-R platelet activation factor receptor; $\mathrm{Ca}$, or $\mathrm{Ca}^{2+}$-intracellular calcium; $\mathrm{P}_{2} \mathrm{Y}_{1}$-purinergic receptor $2 \mathrm{Y}_{1}$; $\mathrm{PAR}_{1}$-protease-activated receptor-1; $\mathrm{PAR}_{4}$-protease-activated receptor-4; IP 3 -inositol 1,4,5-trisphosphate; DTS-dense tubular system; DAG-1,2-diacylglycerol; PKC-protein kinase C; DG-dense granule; AG-alfa-granule; IP-prostacyclin receptor; GC-guanylate cyclase; cAMP-cyclic adenosine monophosphate; cGMP-cyclic guanosine monophosphate; PKA-protein kinase A; PKG-protein kinase G; $\alpha 2 \mathrm{~A}-$ AR-alpha 2A adrenergic receptor; TGF $\beta$-transforming growth factor beta; PDGF-platelet derived growth factor; PF4-platelet factor 4; HMWK-high-molecular-weight kininogen; Fa V-blood coagulation factor V; Fa XI-blood coagulation factor XI; PS-protein S; PAI-plasminogen activator inhibitor; $\mathrm{PgG}_{2}$-prostaglandin $\mathrm{G}_{2} ; \mathrm{PgH}_{2}$-prostaglandin $\mathrm{H}_{2}$; rec.-receptors; other symbols: $\uparrow$-up regulation, $\downarrow$-down-regulation. 


\section{Influence of Exogenous Androgens on Platelet Hemostatic Activity and Thrombopoiesis}

The thrombogenic effect of exogenous androgens is a consequence of them shifting the hemostatic balance towards a procoagulant state.

It has been repeatedly reported that exogenous androgens are able to influence some of the aforementioned pathways leading to enhanced platelet activity. However, beginning with the first report and until today, there have been no extensive studies addressing the influence of androgens on hemostasis in a holistic way, linking platelet activation with humoral coagulation priming. In this paper, we focused on reviewing a segment of the global field of existing data-the effects of exogenous androgens on platelet hemostatic activity and thrombopoiesis.

\subsection{Evidence from Animal Studies}

The dysregulation of both platelet function and thrombopoiesis is recognized to constitute the main cause of arterial thrombosis. Considering the mounting evidence linking AAS misuse with thrombotic events, a more focused study on the effects of androgens on platelet function is needed. The animal experiments conducted to date gathered several lines of evidence to support the stimulatory influence of exogenous androgens on platelet activity and thrombopoiesis (literature summarized in Table 2).

An enhancement of platelet activity as a consequence of androgens treatment in animals was first reported by Johnson et al. (1977) [144]. The first experiment in the study showed sex differences in platelet aggregation in rats and guinea pigs (greater in males than in females). In a second experiment, an increased ex vivo platelet aggregation in response to adenosine diphosphate (ADP, $0.1-10 \mu \mathrm{g} / \mathrm{mL}$ ) following short-term testosterone administration $(1 \mathrm{mg} / \mathrm{kg})$ was observed in female rats. To determine whether androgens have direct effects on platelets, in the absence of other hormonal environments, a third in vitro study was performed. Testosterone $(1 \mu \mathrm{g} / \mathrm{mL})$ was incubated with platelet-rich plasma (PRP) from male rats, and an increased platelet sensitivity in response to ADP $(0.1-1 \mu \mathrm{g} / \mathrm{mL})$ was obtained. Moreover, increasing levels of testosterone ( $91 \mathrm{ng} / \mathrm{mL}$ to $100 \mathrm{ng} / \mathrm{mL}$ ) have been found to potentiate platelet aggregation (enhanced from $18.0 \pm 1.5 \%$ to $62.0 \pm 8.0 \%$ ), when triggered by ADP $(2 \mu \mathrm{g} / \mathrm{mL})$. Finally, using the same turbidimetric technique, the author set a rank scale of the in vitro effectiveness of various androgens on platelet aggregation induced by $2 \mu \mathrm{g} / \mathrm{mL}$ ADP, which was correlated to their androgenicitydihydrotestosterone, testosterone, methyltestosterone, androstendione, and androsterone. The study concluded that the influence of testosterone upon platelet aggregation may provide a mechanism for enhanced thrombus formation [144]. This was in accordance with previous reports indicating the thrombogenic potential of exogenous testosterone when arterial thrombosis has been induced experimentally in several animal models (mice, rats, rabbits) $[93,94]$.

On the other hand, Skjaerlund et al. (1983) found that neither oxandrolone nor testosterone, biweekly administered in a dose of $5 \mathrm{mg} / \mathrm{kg}$ for 2.5 weeks, influenced platelet aggregation triggered by ADP $(40 \mu \mathrm{M})$, collagen, epinephrine $(6 \mu \mathrm{M})$ or arachidonic acid $(130 \mu \mathrm{M})$ in platelets from atherosclerosis-susceptible White Carneau pigeons [145]. Neither of these two drugs had an influence on the synthesis of thromboxane $\mathrm{B}_{2}$ (the more stable product of the pro-aggregatory thromboxane $A_{2}$ ) or other prostaglandins when the platelets suspension was triggered by arachidonic acid. Nevertheless, both drugs stimulated the synthesis of the more stable product prostacyclin (6-keto-prostaglandin $F_{1 \alpha}$ ) and prostaglandin $\mathrm{E}_{2}$ in aortic homogenate of the treated pigeons after platelets suspension incubation with arachidonic acid [145]. 
Table 2. The characteristics of included studies.

\begin{tabular}{|c|c|c|c|c|c|c|}
\hline Reference & $\begin{array}{c}\text { Treated Subjects, Sex, Number } \\
\text { of Subjects Per Group, Type } \\
\text { of Experiment }\end{array}$ & Androgen Formulation & Design of the Study & $\begin{array}{c}\text { Platelet Aggregation } \\
\text { Variation (Agonist) }\end{array}$ & $\begin{array}{c}\text { Outcome from Other } \\
\text { Assays of Platelet Function }\end{array}$ & $\begin{array}{c}\text { Platelet } \\
\text { Count }\end{array}$ \\
\hline \multirow{2}{*}{ Johnson M. 1977 et al. [144] } & Rats, females, $n=8$, ex vivo & Testosterone & $\begin{array}{c}1 \mathrm{mg} / \mathrm{kg} \text {, s.c, } \\
\text { single administration }\end{array}$ & $\uparrow(\mathrm{ADP}-0.1-1 \mu \mathrm{g} / \mathrm{mL})$ & & \\
\hline & Rats, males, $n=8$, in vitro & Testosterone & $\begin{array}{c}1 \mu \mathrm{g} / \mathrm{mL}, 30 \mathrm{~min} \text { before } \\
\text { adding ADP }\end{array}$ & $\uparrow(\mathrm{ADP}-0.1-1 \mu \mathrm{g} / \mathrm{mL})$ & & \\
\hline Skjaerlund JM. 1983 et al. [145] & Pigeons, females, $n=6$, ex vivo & $\begin{array}{l}\text { Testosterone } \\
\text { Oxandrolone }\end{array}$ & $\begin{array}{l}5 \mathrm{mg} / \mathrm{kg}, \text { i.m, biweekly, } \\
\text { for } 2.5 \text { weeks }\end{array}$ & $\begin{array}{l}\text { Neutral (ADP-40 } \mu \mathrm{M}, \\
\text { collagen, epinephr-6 } \mu \mathrm{M}, \\
\text { arach. ac. }-130 \mu \mathrm{M})\end{array}$ & $\begin{array}{c}\text { Neutral effect on } \\
\text { platelet } \mathrm{TxB}_{2} \\
\mathrm{PG} \mathrm{F}_{2 \alpha}, \mathrm{PG} \mathrm{E}_{2} \\
\text { synthesis from } \\
{\left[{ }^{14} \mathrm{C}\right] \text { arach. ac. }} \\
(40 \mathrm{mCi} / \mathrm{mM})\end{array}$ & \\
\hline Rosenblum WI. 1987 et al. [96] & Mice, $n=10$, ex vivo & Testosterone & $\begin{array}{l}\text { Pellets, } 1.0 \mathrm{mg} \text {, s.c, } \\
8-19 \text { days before } \\
\text { the experiment }\end{array}$ & $\begin{array}{c}\uparrow(\text { arach. ac, } 0.25 \mathrm{mM} \\
\text {-male mice) } \\
\text { Neutral (arach.ac, } \\
0.4 \mathrm{mM} \text {-female mice) }\end{array}$ & & \\
\hline Muguruma K. 1993 et al. [146] & $\begin{array}{l}\text { Guinea pigs, castrated males, } \\
\text { ex vivo }\end{array}$ & Testosterone propionate & $\begin{array}{c}1 \mathrm{mg} / \text { day, i.m, for } \\
1 \text { week }\end{array}$ & 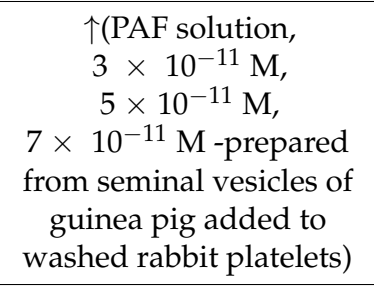 & & \\
\hline \multirow{2}{*}{ Matsuda K. 1994 et al. [147] } & Rats, males, $n=7$, ex vivo & Testosterone cypionate & $\begin{array}{l}10 \mathrm{mg} / \mathrm{kg}, \mathrm{i} . \mathrm{m}, \text { twice } \\
\text { weekly, for } 2 \text { weeks }\end{array}$ & $\begin{array}{l}\uparrow(\mathrm{TC} \text { for I-BOP in A vs. } \\
C \text { group: } 0.07 \pm 0.01 \mathrm{nM} \\
\text { vs. } 0.45 \pm 0.16 \mathrm{nM})\end{array}$ & & \\
\hline & Rats, males, $n=15$, ex vivo & Testosterone cypionate & $\begin{array}{l}10 \mathrm{mg} / \mathrm{kg} \text {, i.m, twice } \\
\text { weekly, for } 2 \text { weeks }\end{array}$ & & $\uparrow \mathrm{B}_{\max }\left(80 \mu \mathrm{L}\right.$ of $\left.\left[{ }^{125} \mathrm{I}\right] \mathrm{BOP}\right)$ & \\
\hline
\end{tabular}


Table 2. Cont.

\begin{tabular}{|c|c|c|c|c|c|c|}
\hline Reference & $\begin{array}{c}\text { Treated Subjects, Sex, Number } \\
\text { of Subjects Per Group, Type } \\
\text { of Experiment }\end{array}$ & Androgen Formulation & Design of the Study & $\begin{array}{l}\text { Platelet Aggregation } \\
\text { Variation (Agonist) }\end{array}$ & $\begin{array}{l}\text { Outcome from Other } \\
\text { Assays of Platelet Function }\end{array}$ & $\begin{array}{c}\text { Platelet } \\
\text { Count }\end{array}$ \\
\hline $\begin{array}{l}\text { Bednarek-Tupikowska G. } \\
2000 \text { et al. }[148]\end{array}$ & Rabbits, male, $n=11$, ex vivo & DHEA & $\begin{array}{l}0.5 \% \text { of DHEA added to } \\
\text { diet }(0.125 \mathrm{~g} / \mathrm{kg} / \text { day }) \\
\text { for } 12 \text { weeks }\end{array}$ & $\begin{array}{c}\text { Neutral } \\
\text { (ADP-5 } \mu \mathrm{mol} / \mathrm{mL}, \\
\text { collagen-2 } \mu \mathrm{mol} / \mathrm{mL})\end{array}$ & & \\
\hline Aydilek N. 2005 et al. [149] & Rabbits, males, $n=8$, ex vivo & Testosterone propionate & $\begin{array}{l}10 \text { mg, s.c, every other } \\
\text { day, for } 6 \text { weeks }\end{array}$ & & & $\uparrow$ \\
\hline Alhawiti NM. 2018 et al. [151] & Rats, males, $n=10$, ex vivo & Testosterone propionate & $\begin{array}{l}0.5 \mathrm{mg} / \mathrm{kg} \text {, three times } \\
\text { per week, for } 12 \text { weeks }\end{array}$ & Neutral (ADP-10 $\mu \mathrm{M})$ & & Neutral \\
\hline Roşca A. 2013 et al. [152] & Rats, males, $n=10$, ex vivo & DECA & $\begin{array}{l}10 \mathrm{mg} / \mathrm{kg} \text {, i.m, weekly, } \\
\text { for } 3 \text { months }\end{array}$ & $\uparrow(\mathrm{ADP}-2.5 \mu \mathrm{M})$ & & \\
\hline Roşca A. 2013 et al. [153] & Rats, males, $n=10$, ex vivo & DECA & $\begin{array}{l}10 \mathrm{mg} / \mathrm{kg} \text {, i.m, weekly, } \\
\text { for } 3 \text { months }\end{array}$ & & $\begin{array}{l}\uparrow \text { Maximal clot strength and } \\
\text { stability }\end{array}$ & \\
\hline
\end{tabular}

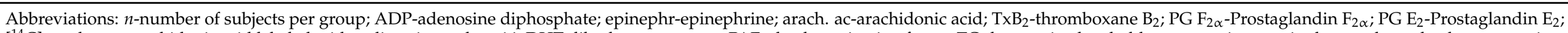

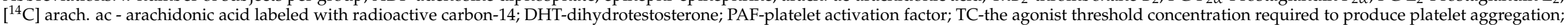

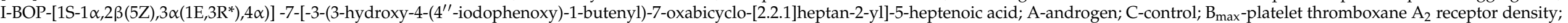

$\left[{ }^{125}\right.$ I]BOP-radioactive I-BOP; DHEA-Dehydroepiandrosterone; DECA-nandrolone decanoate; other symbols: $\uparrow$-up regulation, $\downarrow$-down-regulation. 
Several years later, an ex vivo study conducted by Rosenblum and co-workers (1987) showed that testosterone-implanted pellets $(1.0 \mathrm{mg})$ enhanced platelet aggregation in male, but not in female, mice, when PRP was incubated with sodium arachidonate $(0.25 \mathrm{mM}$ and $0.4 \mathrm{mM}$, respectively) [96]. No response was observed after DHT $(0.1 \mathrm{mg})$ pellet implantation in mice of either sex, when platelet aggregation was triggered with arachidonic acid or $\operatorname{ADP}(0.25 \mu \mathrm{M})[96]$.

As seminal vesicles are a target organ of androgens action, Muguruma et al. (1993) examined the effect of testosterone on platelet-activating factor (PAF) activity in the seminal vesicles of guinea pigs [146]. PAF activity decreased to $50 \%$ of the normal level at 2 weeks after castration, while further testosterone propionate administration ( $1 \mathrm{mg} /$ day, for 1 week) increased to $136 \%$ PAF activity compared to intact animals [146].

In a fairly similar way, short-term testosterone cypionate administration $(10 \mathrm{mg} / \mathrm{kg}$, twice weekly, for 2 weeks) caused a significant reduction in the threshold concentration of the TxA $A_{2}$ analog I-BOP ([1S- $\left.\left.1 \alpha, 2 \beta(5 Z), 3 \alpha\left(1 \mathrm{E}, 3 \mathrm{R}^{*}\right), 4 \alpha\right)\right]-7-[-3$-(3-hydroxy-4-(4'-iodophenoxy)1-butenyl)-7-oxabicyclo-[2.2.1] heptan-2-yl]-5-heptenoic acid), necessary to produce platelet aggregation in the PRP from male rats $(0.07 \pm 0.01 \mathrm{nM}$ in the testosterone-exposed group versus $0.45 \pm 0.16 \mathrm{nM}$ in the control group). Moreover, using a radioligand binding assay, short-term testosterone treatment was shown to significantly increase $\mathrm{TxA}_{2}$ receptor density in platelets $(42.9 \pm 4.2 \mathrm{fmol} / \mathrm{mg}$ protein for the testosterone-treated group versus $25.4 \pm 3.2 \mathrm{fmol} / \mathrm{mg}$ protein for controls), while the $\mathrm{TxA}_{2}$ receptor affinity remained unchanged. Therefore, increasing the $\mathrm{TxA}_{2}$ receptor density might be an important mechanism underlying the thrombogenic potential of supraphysiological androgens, acting by enhancing platelet aggregation [147].

Supporting the putative pro-aggregant action of suprapharmacological AAS, we have shown in a previous published study that high doses of nandrolone decanoate (DECA), chronically administered (10 mg/kg body weight, for 12 weeks) (a situation analogous to steroid abuse), induced a significant increase in platelet aggregation triggered by ADP $(2.5 \mu \mathrm{M})$ in the PRP from male Wistar rats [152]. This is consistent with other findings we have reported. Using the thromboelastographic method to analyze changes in the shear elasticity of clotting blood, supraphysiological DECA administration in rats showed an increase in maximal clot strength and stability (MA), which largely depends on platelet function (platelet bonding via GP Ilb/IIIa) [153].

Dehydroepiandrosterone (DHEA) is an adrenal steroid and an intermediate metabolite within the androgenic pathway (prohormone), leading to the production of both androgens and estrogens. Having a weaker androgenicity, it started to be used and promoted on the bodybuilding market as a dietary supplement for gaining strength. Both human and animal studies reported beneficial effects of DHEA, including the downregulation of platelet activity. Bednarek-Tupikowska et al. (2000) noted that DHEA has no effect on platelet aggregation (following ADP $5 \mu \mathrm{mol} / \mathrm{mL}$ or collagen $2 \mu \mathrm{mol} / \mathrm{mL}$ stimulation), but she observed an increase in platelet superoxide dismutase activity (which can modulate platelet function) when the steroid was administered $0.5 \%$ in the diet (about $0.125 \mathrm{~g} / \mathrm{kg} /$ day) for 12 weeks in either healthy or hyperlipidemic rabbits [148].

Several studies showed that androgen excess also stimulates thrombopoiesis, and it could increase the thrombotic risk when it is associated with an enhanced platelet aggregation $[154,155]$. Testosterone propionate, administered in a dose of $10 \mathrm{mg}$ every other day for 6 weeks, enhanced platelet count in New Zealand intact male rabbits, while castration had an opposite effect [149]. In another study, the castration of BALB/c mice (an albino, laboratory-bred strain of the house mouse) resulted in a decrease in erythropoiesis and thrombopoiesis (decrease in platelet count, platelet size, sulfur 35 incorporation into platelets, mean megakaryocyte ploidy, and total circulating platelet mass and count). Testosterone administration in maintenance doses for several days restored platelet production, raising the possibility that it may act on the bipotential hematopoietic precursor cell [150]. A recent trial conducted in healthy male Sprague-Dawley rats evidenced a lack of effect of testosterone propionate on platelet count, platelet aggregation (using $10 \mu \mathrm{M}$ 
ADP as agonist), and thromboxane $\mathrm{A}_{2}\left(\mathrm{TxB}_{2}\right)$ serum level, when chronically administered in high doses $(0.5 \mathrm{mg} / \mathrm{kg}$, three times per week for 12 weeks). The author concluded that supraphysiological doses of testosterone in healthy rats (and also the right dose required to normalize plasma testosterone levels in cases of testosterone deficiency) act as a cardioprotective agent, with beneficial effects on hemostasis by enhancing the fibrinolytic activity and eliciting hypocoagulation [151].

In physiological administration, androgens seem to exert an inhibiting effect on platelet activity. DHT replacement in castrated male rats (at a dose of $0.25 \mathrm{mg} / \mathrm{rat}$, for 2 weeks, which restored the serum DHT to physiological level) exhibited a suppression of ADP-induced platelet aggregation and adhesion, $\mathrm{H}_{2} \mathrm{O}_{2}$-induced platelet aggregation and $\mathrm{TxA}_{2}$ release from platelets, and induced a significant decrease in plasmatic $\mathrm{TxB}_{2} / 6$-keto-PGF $1 \alpha$ ratio. All androgen effects were reversed by flutamide administration. As physiological levels of testosterone also inhibited experimental arterial thrombosis in rats, it was concluded that all these effects might be ascribed to the complex androgen modulation of platelet activation $[97,156]$. Another group of researchers published several in vitro studies showing that the pretreatment of endothelial cell cultures from rats with testosterone at physiological concentrations completely abolished the increased platelet adhesion induced by lipopolysaccharide proinflammatory stimulus, inhibited the ADPinduced platelet aggregation in PRP incubated with endothelial cells, and stimulated the endothelial cell growth, in a releasing NO-dependent manner. It has been suggested that the antiaggregatory action of androgens at physiological levels could be dependent on NO release from the endothelial cells. As both the modulation of vasodilators synthesis and platelet function are key processes of atherosclerosis, serum physiological testosterone may help in preventing atherosclerotic degeneration [157-159].

We can conclude that animal studies provide evidence to a certain extent about the putative role of supraphysiological androgens in enhancing platelet hemostatic activity and thrombopoiesis. However, the lack of more comprehensive data, the multitude of limitations in study design, the relative scarcity of underlying mechanisms, and even the contradictory findings related to various androgens formulations, make it difficult to translate this overall negative influence of exogenous androgens on platelet function and count to a procoagulant state induced by these steroids, especially in terms of thrombotic risk.

\subsection{Evidence from Human Studies}

A considerable number of studies have been developed so far on the influence of exogenous androgens on human platelets. Most data come from in vitro studies, observational studies, and from prospective studies in patients suffering from a chronic certain disease, and thus assume that they followed a long-term steroid regimen. Unfortunately, few cross-sectional studies exploring platelet activity in AAS-abusing athletes have been achieved, and for ethical reasons, there are far fewer prospective studies in healthy men (most, if not all, with short-term AAS administration).

For easier reading, a split based on studies using in vitro and ex vivo platelet function testing has been established. The representative articles have been summarized in Table 3. 
Table 3. The characteristics of included studies.

\begin{tabular}{|c|c|c|c|c|c|c|}
\hline Reference & $\begin{array}{l}\text { Human subjects, Number of } \\
\text { Individuals Per Group }\end{array}$ & $\begin{array}{l}\text { Androgen } \\
\text { Formulation }\end{array}$ & Design of the Study & $\begin{array}{l}\text { Platelet Aggregation } \\
\text { Variation (Agonist) }\end{array}$ & $\begin{array}{l}\text { Outcome from Other Assays of } \\
\text { Platelet Function, or from Tests } \\
\text { Involving Cellular Lineage (Agonist) }\end{array}$ & $\begin{array}{c}\text { Platelet } \\
\text { Count }\end{array}$ \\
\hline \multicolumn{7}{|l|}{ In vitro } \\
\hline $\begin{array}{l}\text { Johnson M. } \\
1975 \text { et al. [160] }\end{array}$ & Healthy men and women & Testosterone & $\begin{array}{l}1 \mu \mathrm{g} / \mathrm{mL}, 30 \mathrm{~min} \text { before } \\
\text { adding agonist }\end{array}$ & $\begin{array}{l}\uparrow(\mathrm{ADP}-1 \mu \mathrm{g} / \mathrm{mL} \text {, } \\
\text { adrenaline- } 10 \mu \mathrm{M} \text {, } \\
\text { collagen-30 } \mu \mathrm{L} \text {, arach. } \\
\text { ac-1 } \mathrm{mM})\end{array}$ & & \\
\hline $\begin{array}{l}\text { Togna GI. } \\
2003 \text { et al. [162] }\end{array}$ & Healthy volunteers & $\begin{array}{l}\text { Testosterone and } \\
\text { cocaine }\end{array}$ & $\begin{array}{l}\text { - Testosterone } 0.75 \mu \mathrm{M} \\
\text { and cocaine } 50 \text { or } \\
100 \mu \mathrm{M}, 10 \mathrm{~min} \\
\text { - Testosterone } 1.5 \mu \mathrm{M} \\
\text { and cocaine } 100 \mu \mathrm{M} \text {, } \\
10 \text { min }\end{array}$ & 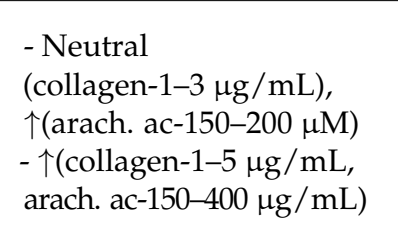 & $\begin{array}{l}\text { - Neutral on platelet } \mathrm{TxB}_{2} \text { production } \\
\text { (collagen-1-3 } \mathrm{\mu g} / \mathrm{mL} \text { ); } \uparrow \text { platelet } \mathrm{TxB} \mathrm{B}_{2} \\
\text { production }(\text { arach. ac- } 150-200 \mu \mathrm{M} \text { ) } \\
\text { - } \uparrow \text { platelet } \mathrm{TxB} \mathrm{B}_{2} \text { production } \\
\text { (collagen- } 1-5 \mu \mathrm{g} / \mathrm{mL} \text {, arach. } \\
\text { ac- } 150-400 \mu \mathrm{g} / \mathrm{mL} \text { ) }\end{array}$ & \\
\hline $\begin{array}{l}\text { Banerjee D. } \\
2014 \text { et al. [163] }\end{array}$ & $\begin{array}{l}\text { - Healthy male volunteers } \\
\text { - Healthy female volunteers }\end{array}$ & $\begin{array}{l}\text { - Testosterone } \\
\text { - Testosterone }\end{array}$ & $\begin{array}{l}-40 \mathrm{nM}, 40 \mathrm{~min} \\
-40 \mathrm{nM}, 40 \mathrm{~min}\end{array}$ & $\begin{array}{l}\text { - } \uparrow(\mathrm{ADP}-2 \mu \mathrm{M}) \\
\text { - Neutral (ADP-2 } \mu \mathrm{M})\end{array}$ & $\begin{array}{l}-\downarrow \text { platelet } \mathrm{NO}, \uparrow \text { platelet } \mathrm{TxA}_{2} \\
\text { synthesis (ADP-2 } \mu \mathrm{M}) ; \\
\text { - Neutral on platelet NO, and } \mathrm{TxA}_{2} \\
\text { synthesis (ADP-2 } \mu \mathrm{M} \text { ) }\end{array}$ & \\
\hline Lee SJ. 2012 et al. [164] & $\begin{array}{l}\text { Human megakaryocytic DAMI } \\
\text { cell line }\end{array}$ & Testosterone & $\begin{array}{l}50 \mathrm{nM}, 150 \mathrm{nM}, 450 \mathrm{nM} \text {, } \\
\text { for } 36 \mathrm{~h} \text {. }\end{array}$ & & $\begin{array}{l}\uparrow \mathrm{P}_{2} \mathrm{Y}_{12} \mathrm{mRNA} \text { and } \mathrm{P}_{2} \mathrm{Y}_{12} \text { protein level } \\
\text { in a dose-dependent manner }\end{array}$ & \\
\hline $\begin{array}{l}\text { Matsuda K. } 1993 \text { et al. } \\
\text { [165], Halushka PV. } 1994 \\
\text { et al. [166] }\end{array}$ & Human erythroleukemia cells & $\begin{array}{l}\text { - Testosterone } \\
\text { - DHT }\end{array}$ & $\begin{array}{l}-200 \mathrm{nM}, \text { for } 24 \mathrm{~h} \\
-75,100,200 \mathrm{nM}, \text { for } 24 \mathrm{~h}\end{array}$ & & $\begin{array}{l}\uparrow \mathrm{B}_{\max }\left(\left[{ }^{125} \mathrm{I}\right] \mathrm{BOP}-50 \mathrm{pM}\right) \text { following } \mathrm{T} \\
\text { and DHT administration; } \uparrow\left[\mathrm{Ca}^{2+}\right]_{\mathrm{i}} \\
\left(\left[{ }^{125} \mathrm{I}\right] \mathrm{BOP}-100 \mathrm{nM} \text {, or } \mathrm{U}-46619\right) \text { for } \mathrm{T} \\
\text { administration }\end{array}$ & \\
\hline $\begin{array}{l}\text { Zucker TP. } \\
1996 \text { et al. [167] }\end{array}$ & Human erythroleukemia cells & $\begin{array}{l}\text { - Testosterone; } \\
\text { - } \\
\text { Androstenedione }\end{array}$ & $\begin{array}{l}-150 \mathrm{nM}, \text { for } 48 \mathrm{~h} \\
-250,500 \text { or } 750 \mathrm{nM} \text {, } \\
\text { for } 48 \mathrm{~h}\end{array}$ & & $\uparrow B_{\max }\left(\left[{ }^{125} \mathrm{I}\right] \mathrm{BOP}-60 \mathrm{pM}\right)$ & \\
\hline Jesse RL. 1995 et al. [168] & Healthy donors & DHEAS & $\begin{array}{l}0.075,0.15 \text {, or } 0.3 \mathrm{mM} \text {, } \\
\text { for } 1 \mathrm{~min}\end{array}$ & $\downarrow$ (arachidonic acid) & $\downarrow \mathrm{TxB}_{2}$ synthesis (arachidonic acid) & \\
\hline
\end{tabular}


Table 3. Cont.

\begin{tabular}{|c|c|c|c|c|c|c|}
\hline Reference & $\begin{array}{l}\text { Human subjects, Number of } \\
\text { Individuals Per Group }\end{array}$ & $\begin{array}{l}\text { Androgen } \\
\text { Formulation }\end{array}$ & Design of the Study & $\begin{array}{l}\text { Platelet Aggregation } \\
\text { Variation (Agonist) }\end{array}$ & $\begin{array}{l}\text { Outcome from Other Assays of } \\
\text { Platelet Function, or from Tests } \\
\text { Involving Cellular Lineage (Agonist) }\end{array}$ & $\begin{array}{l}\text { Platelet } \\
\text { Count }\end{array}$ \\
\hline $\begin{array}{l}\text { Bertoni A. } \\
2012 \text { et al. [169] }\end{array}$ & Healthy donors & DHEAS & $\begin{array}{l}-0.068 \times 10^{-4} \mathrm{M} \text {, for } \\
1 \mathrm{~min} ; \\
-3 \times 10^{-4} \mathrm{M} \text {, for } 1 \mathrm{~min}\end{array}$ & $\begin{array}{l}-\downarrow(\text { thrombin- } 0.05 \mathrm{U} / \mathrm{mL}, \\
0.025 \mathrm{U} / \mathrm{mL}, 0.02 \mathrm{U} / \mathrm{mL}) \\
-\downarrow\left(\text { collagen- } 2 \times 10^{-6} \mathrm{~g} / \mathrm{mL},\right. \\
\text { thrombin- } 0.05 \mathrm{U} / \mathrm{mL} \\
\left.\mathrm{U} 46619-1 \times 10^{-6} \mathrm{M}\right)\end{array}$ & $\begin{array}{l}\text { Activation of platelet } \\
\text { NOS/cGMP/PKG pathway (DHEAS at } \\
\left.3 \times 10^{-4} \mathrm{M}\right)\end{array}$ & \\
\hline $\begin{array}{l}\text { Munoz YC. } \\
2012 \text { et al. [170] }\end{array}$ & $\begin{array}{l}\text { Postmenopausal women, } \\
\text { type II diabetes mellitus }\end{array}$ & DHEA & $100 \mathrm{nmol} / \mathrm{L}$, for $20 \mathrm{~min}$ & $\downarrow(\mathrm{ADP}-10 \mu \mathrm{mol} / \mathrm{L})$ & $\begin{array}{l}\text { Activation of platelet } \\
\text { PKC } / \text { eNOS/NO/cGMP pathway }\end{array}$ & \\
\hline \multicolumn{7}{|l|}{ Ex vivo } \\
\hline $\begin{array}{l}\text { Ferenchick G. } \\
\text { 1992b et al. [29] }\end{array}$ & $\begin{array}{l}\text {-Weightlifters, } n=24 \text { for A users; } \\
\text {-Weightlifters, } n=13 \text { for A users, } \\
\text { stratified by age }\end{array}$ & $\begin{array}{l}\text { Various type } \\
\text { AAS intake (an } \\
\text { average of three } \\
\text { separate } \\
\text { AAS/each user) }\end{array}$ & $\begin{array}{l}\text { Various doses and length } \\
\text { of AAS use }\end{array}$ & $\begin{array}{l}\text { - Neutral [TC in AU vs. N } \\
\text { group: } 2.50 \pm 0.21 \mu \mathrm{M} / \mathrm{mL} \\
\text { vs. } 2.90 \pm 1.10 \mu \mathrm{M} / \mathrm{mL} \\
\text { (for ADP); } \\
2.50 \pm 0.38 \mu \mathrm{g} / \mathrm{mL} \text { vs. } \\
1.96 \pm 1.11 \mu \mathrm{g} / \mathrm{mL} \text { (for } \\
\text { collagen)]; } \\
\text { - } \uparrow(\text { age subgroup analysis, } \\
\text { TC for collagen in } \\
\text { AU }>22 \text { yo vs. AU } \leq 22 \text { yo } \\
\text { group: } 1.47 \mu \mathrm{g} / \mathrm{mL} \text { vs. } \\
3.35 \mu \mathrm{g} / \mathrm{mL} \text { ) }\end{array}$ & & Neutral \\
\hline Ajayi AA. 1995 et al. [83] & Healthy men, $n=9$ & $\begin{array}{l}\text { Testosterone } \\
\text { cypionate }\end{array}$ & $\begin{array}{l}200 \mathrm{mg} \text {, i.m, given twice, } \\
2 \text { weeks apart }\end{array}$ & $\begin{array}{l}-\uparrow\left(\mathrm{TxA}_{2} \text { analog }\right. \\
\mathrm{I}-\mathrm{BOP}-0.25 \text { to } 100 \mathrm{nmol} / \mathrm{L}) \\
\text { - Neutral } \\
\text { (thrombin- } 0.00625 \text { to } \\
0.1 \mathrm{U} / \mathrm{mL} \text { ) }\end{array}$ & $\uparrow \mathrm{B}_{\max }\left(\left[{ }^{125} \mathrm{I}\right] \mathrm{BOP}-80 \mu \mathrm{L}\right)$ & \\
\hline $\begin{array}{l}\text { Kahn NN. } \\
2006 \text { et al. [171] }\end{array}$ & Healthy subjects, $n=14$ & Oxandrolone & $\begin{array}{l}10 \mathrm{mg} \text {, twice daily, for } \\
2 \text { weeks }\end{array}$ & Neutral (ADP) & & \\
\hline Jesse RL. 1995 et al. [168] & Healthy men, $n=5$ & DHEA & $\begin{array}{l}300 \mathrm{mg} \text {, p.o, } 3 \text { times } \\
\text { daily, for } 14 \text { days }\end{array}$ & $\downarrow$ (arachidonic acid) & & \\
\hline
\end{tabular}


Table 3. Cont.

\begin{tabular}{|c|c|c|c|c|c|}
\hline Reference & $\begin{array}{l}\text { Human subjects, Number of } \\
\text { Individuals Per Group }\end{array}$ & $\begin{array}{l}\text { Androgen } \\
\text { Formulation }\end{array}$ & Design of the Study & $\begin{array}{l}\text { Outcome from Other Assays of } \\
\text { Platelet Function, or from Tests } \\
\text { Involving Cellular Lineage (Agonist) }\end{array}$ & $\begin{array}{l}\text { Platelet } \\
\text { Count }\end{array}$ \\
\hline Liu W. 2016 et al. [172] & Patients with ITP, $n=103$ & Danazol & $\begin{array}{l}200 \text { or } 300 \text { mg daily, for a } \\
\text { median duration of } \\
7 \text { months }\end{array}$ & & $\uparrow$ \\
\hline \multirow[t]{2}{*}{$\begin{array}{l}\text { Colunga-Pedraza PR. } \\
2018 \text { et al. [173] }\end{array}$} & Patients with MDS, $n=42$ & Danazol & $\begin{array}{l}\text { Median dose of } \\
400 \mathrm{mg} / \text { day, median } \\
\text { follow-up of } 12 \text { months }\end{array}$ & & $\uparrow$ \\
\hline & $\begin{array}{l}\text { Bodybuilders and powerlifters, } \\
n=17 \text { (AAS abusers); } \\
n=15 \text { (AAS ex-abusers) }\end{array}$ & $\begin{array}{l}\text { Heterogenous } \\
\text { AAS intake }\end{array}$ & $\begin{array}{l}\text { Mean dosage of } \\
750 \mathrm{mg} \text { /week, } 33 \text { weeks } \\
\text { per year, over } 8 \text { years } \\
\text { (AAS abusers); mean } \\
\text { dosage } 700 \mathrm{mg} \text { / week, } \\
\text { for } 26 \text { weeks per year, } \\
\text { over } 9 \text { years (AAS } \\
\text { ex-abusers) }\end{array}$ & & $\uparrow$ \\
\hline $\begin{array}{l}\text { Ansell JE. } \\
1993 \text { et al. [174] }\end{array}$ & Bodybuilders, $n=11$ & $\begin{array}{l}\text { Various type of } \\
\text { AAS intake, } \\
3 \text { different } \\
\text { AAS/each user } \\
\text { (average) }\end{array}$ & $\begin{array}{l}\text { Various doses and length } \\
\text { of AAS intake }\end{array}$ & & $\uparrow$ \\
\hline $\begin{array}{l}\text { Severo CB. } \\
2013 \text { et al. [175] }\end{array}$ & Weightlifters, $n=10$ & $\begin{array}{l}\text { Various type of } \\
\text { AAS intake, } \\
3 \text { different } \\
\text { AAS/each user } \\
\text { (average) }\end{array}$ & $\begin{array}{l}\text { Various doses and length } \\
\text { of AAS intake }\end{array}$ & & $\uparrow$ \\
\hline $\begin{array}{l}\text { Zitzmann M. } \\
2002 \text { et al. [176] }\end{array}$ & Healthy men, $n=14$ & $\begin{array}{l}\text { Testosterone } \\
\text { undecanoate }\end{array}$ & $\begin{array}{l}1000 \mathrm{mg}, \text { i.m, in study } \\
\text { weeks } 0,6,12 \text {, and } 18\end{array}$ & & Neutral \\
\hline
\end{tabular}




\subsubsection{Studies Using In Vitro Platelet Function Assay}

Compared to ex vivo studies, the in vitro human studies use platelets from blood samples harvested from healthy donors, or cellular lineage, which are incubated with exogenous androgens, thus eluding the ethical implications linked to their administration in humans.

Johnson and colleagues were the first to publish a human study testing platelet aggregation after incubation with androgens (Nature, 1975) [160]. Once they detected sex differences in platelet sensitivity to aggregating stimuli in the ex vivo part of the study (which was greater in females than in males, in contrast with the data coming from the experiment conducted in animals), they further investigated the in vitro platelets responsiveness to various agonists (ADP $1 \mu \mathrm{g} / \mathrm{mL}$, adrenaline $10 \mu \mathrm{M}$, collagen $30 \mu \mathrm{L}$, arachidonic acid $1 \mathrm{mM}$ ). An increased platelet aggregation was detected when testosterone in a dose of $1 \mu \mathrm{g} / \mathrm{mL}$ was incubated with human PRP [160].

Later, Pilo et al. (1981) demonstrated that testosterone can increase the ionophore A23187-inducing platelet aggregation in human washed platelets and PRP, in a dose- and time-dependent manner, accompanied by concomitant $\mathrm{TxA}_{2}$ and other prostaglandin products generation [161]. A more recent study showed that testosterone in concentrations not normally exerting any appreciably acute effects per se $(0.75 \mu \mathrm{M}$, or $1.5 \mu \mathrm{M})$ is capable of potentiating cocaine's effect on platelet function, in terms of enhancing $\mathrm{TxB}_{2}$ release (the stable metabolite of $\mathrm{TxA}_{2}$ ) and augmenting the aggregation response to arachidonate $(150-200 \mu \mathrm{g} / \mathrm{mL})$ and collagen $(5 \mu \mathrm{g} / \mathrm{mL}$ for $0.75 \mu \mathrm{M}$ testosterone, and $1-5 \mu \mathrm{g} / \mathrm{mL}$ for $1.5 \mu \mathrm{M}$ testosterone). The author concluded that testosterone may supplementarily increase thrombotic risk when concomitantly used with cocaine [162].

On the other hand, androgens have been noted to interfere with platelet NO production. The pretreatment of healthy male PRP with testosterone $(40 \mathrm{nM})$ led to a reduction in platelet NO level, which resulted in an increased synthesis of the pro-aggregant prostaglandin $\mathrm{TxA}_{2}$ and increased platelet aggregation, when triggered with $2 \mu \mathrm{M}$ ADP. This effect has not been shown in platelets from female subjects incubated with testosterone. The inhibition of the cytosolic NOSactivity by testosterone, leading to the reduction of platelet NO level, was found to occur only in platelets from male subjects, suggesting a unique sex-specific effect of testosterone. This might explain the increased occurrence of acute coronary syndrome (ACS) in males. This also suggests that flutamide (a testosterone receptor blocker) might decrease the incidence of ACS in males suffering from prostate cancer [163].

In another in vitro study, testosterone incubated with a human megakaryocytic DAMI cells showed an upregulation of androgen receptors (AR) expression at 1, 5 and $10 \mathrm{nmol} / \mathrm{L}$ concentrations, followed by a downregulation of AR expression at $100 \mathrm{nmol} / \mathrm{L}$ concentration (DAMI cells are a cellular lineage generated ex vivo from normal human CD34(+) stem cells, often used instead of platelets that do not have nuclei, in order to study the molecular regulation of gene expression by an exogenous agents) [177]. In the same megakaryocytic cellular line, testosterone $(50,150,450 \mathrm{nM})$ has been proven to regulate in a dose-dependent manner the gene expression and protein level of $\mathrm{P}_{2} \mathrm{Y}_{2}$, which is an important $\mathrm{G}$ proteincoupled receptor involved in ADP-induced platelet aggregation. Conversely, no effect has been recorded after the treatment of this cellular lineage with 17 $\beta$-estradiol [164].

It has also been shown that testosterone $(200 \mathrm{nM})$ and dihydrotestosterone $(75,100$, $200 \mathrm{nM})$ increased the $\mathrm{TxA}_{2} /$ prostaglandin $\mathrm{H}_{2}\left(\mathrm{PGH}_{2}\right)$ receptor density, but did not change the receptor affinity in human erythroleukemia (HEL) cells, an effect identified to be mediated through $\mathrm{AR}$, and which might be the result of the new $\mathrm{TxA}_{2} / \mathrm{PGH}_{2}$ receptors synthesis by HEL cells $[165,166]$. Another important finding emerging from this study was the association between increased $\mathrm{TxA}_{2}$ receptor density and intracellular signaling following $\mathrm{TxA}_{2}$ receptor binding. Testosterone induced an enhancement of intracellular free calcium in HEL cells, triggered by $\mathrm{TxA}_{2} / \mathrm{PGH}_{2}$ agonists (I-BOP or U-46619) [165]. As platelets have been shown to convert androstenedione to testosterone, the same research group resumed the experiments several years later and demonstrated that androstene- 
dione, in an in vitro dose of 250,500 or $750 \mathrm{nM}$, is able to increase the maximum number of $\mathrm{TxA}_{2}$-binding sites in HEL cells in response to agonist I-BOP, an effect completely antagonized by receptor antagonist hydroxyflutamide $(2.5 \mu \mathrm{M}$, when incubated with $500 \mathrm{nM}$ androstenedione). This finding raised the possibility that adrenal androgen regulates $\mathrm{Tx}_{2}$ receptor expression either on its own, or via conversion to testosterone, an effect mediated through AR [167].

DHEAS (DHEA-sulfated, the main form in which DHEA circulates in blood) administered in vitro $(0.075,0.15$, or $0.3 \mathrm{mM})$ revealed a dose- and time-dependent inhibition of arachidonate-induced platelet aggregation in human pooled PRP, as well as a reduction in platelet $\mathrm{TxB}_{2}$ synthesis [168]. Similarly, DHEAS inhibited platelet aggregation at either a physiological dose $\left(0.068 \times 10^{-4} \mathrm{M}\right)$, when triggered by thrombin $(0.05,0.025$, and $0.02 \mathrm{U} / \mathrm{mL})$, or a supraphysiological dose $\left(3 \times 10^{-4} \mathrm{M}\right)$ when triggered by collagen $\left(2 \times 10^{-6} \mathrm{~g} / \mathrm{mL}\right.$, aggregation decreased by $\left.63.34 \pm 9.38 \%\right)$, thrombin $(0.05 \mathrm{U} / \mathrm{mL}$, aggregation decreased by $64.58 \pm 19.96 \%)$, and $\mathrm{TxA}_{2}$ analog U-46619 $\left(1 \times 10^{-6} \mathrm{M}\right.$, aggregation decreased by $55.56 \pm 18.73 \%$ ). Interestingly, DHEA at either a physiological concentration $\left(1 \times 10^{-4} \mathrm{M}\right)$ or a 44 -fold higher concentration presented no effect on platelet aggregation, when stimulated with $0.05 \mathrm{U} / \mathrm{mL}$ thrombin. Additionally, DHEA at a physiological concentration did not inhibit platelet aggregation following stimulation with $2 \times 10^{-6} \mathrm{~g} / \mathrm{mL}$ collagen and $1 \times 10^{-6} \mathrm{M} \mathrm{U}-46619$. The author speculated that such a variability in DHEAS and DHEA's effect on platelet aggregation may be ascribed to the difference in the platelet membrane's permeability to these compounds. In the same study, it has been shown that DHEAS inhibits platelet dense granule secretion and protein phosphorylation caused by thrombin, therefore playing a major role in the inhibition of ADP secretion. Moreover, both DHEA and DHEAS are able to activate the NOS/cGMP/PKG (nitric oxide synthase/cyclic guanosine monophosphate/protein kinase G) pathway in human platelets [169]. Concomitantly, another study demonstrated that DHEA (100 nmol/L) prevented ADP $(10 \mu \mathrm{mol} / \mathrm{L})$-induced platelet aggregation by $40 \%$ compared with controls, increased platelet NO production by $63 \%$, increased the levels of phosphorylated endothelial NOS, and increased platelet cGMP production, when incubated with PRP from postmenopausal women with type 2 diabetes mellitus. These effects have been associated with the activation of the platelet PKC $\delta / e N O S / N O / c G M P$ (protein kinase C-delta/endothelial NOS/NO/cGMP) pathway [170].

Probably one of the most challenging assumptions that has emerged in recent decades, regarding the effect of androgens on platelet activity, is that platelets are able to uptake and convert sex steroids to their active compounds, or even to generate them from cholesterol under pathological conditions. In 2008, Sarabia et al. noted that platelets from healthy men predominantly deposit testosterone, while platelets from healthy premenopausal women predominantly deposit estradiol [178]. They evidenced a tenfold greater plasma testosterone level, and also a more than threefold greater platelet testosterone level, in males than in premenopausal or postmenopausal women [178]. It has been previously proven that human platelets express both androgen and estrogen receptors, as well as the steroidogenic dehydrogenases involved in testosterone production, being able to transform androstenedione into potent androgens [147,179-182]. Furthermore, in 2012, Garrido et al. demonstrated that human platelets can import DHEAS or estrone-sulfate and convert it to DHEA (the potential precursor used for the synthesis of sex steroids) and 17 $\beta$-estradiol, suggesting an intracrine capacity of human platelets to "produce" sex hormones [183]. Recently, a trial conducted by Zaslavsky et al. identified a fully intact pathway for testosterone de novo biosynthesis from cholesterol in platelets from patients with castration-resistant prostate cancer and resistance to androgen deprivation therapy [184]. Additionally, a pool of platelet-derived androgens from these patients was proven to be sufficient to induce androgen receptor signaling in prostate neoplastic cells, leading to the growth of prostate cancer. The authors concluded that the novel paracrine mechanism of testosterone synthesis in platelets to functionally relevant levels may explain the castration-resistant status of 
prostate cancer, and the relapse after androgen-ablative therapies, therefore suggesting a new therapeutic target centered on extragonadal androgen biosynthesis [184].

\subsubsection{Studies Using Ex Vivo Platelet Function Assay}

The earliest cross-sectional study regarding the effects of AAS abuse on platelet function was conducted by Ferenchick et al. (1992) in 28 recruited weightlifters [29]. A statistically nonsignificant trend toward increased platelet count and aggregation induced by ADP was registered (the agonist threshold concentration required to produce platelet aggregation in AAS users versus nonusers was $2.50 \pm 0.21 \mu \mathrm{M} / \mathrm{mL}$ versus $2.90 \pm 1.10 \mu \mathrm{M} / \mathrm{mL}$ ). However, an association between age and increased platelet responsiveness to collagen was noted in a subgroup analysis (androgen users older than 22 years old had a significantly lower collagen threshold concentration, compared to those under 22 years old; $1.47 \mu \mathrm{g} / \mathrm{mL}$ versus $3.35 \mu \mathrm{g} / \mathrm{mL}$ ). The study had several limitations (unexpected findings on urine screens for the presence of exogenous androgens in declared nonusers, heterogeneous AAS self-administration with an average of three separate androgens for each declared user, and a low number of controls) probably explaining the contradictory results. The author concluded that these findings may, however, be useful to explain the previous reported thrombotic disease in the population of AAS users [29].

Later, in a double-blind, randomized and placebo-controlled study conducted by Ajayi et al. (1995) in 16 healthy men, $200 \mathrm{mg}$ of intramuscular testosterone cypionate, given twice 2 weeks apart, determined a significant increase in maximum platelet aggregation $(5.2 \pm 1.6 \%$ at 2 weeks, a peak effect of $+7.3 \pm 2.3 \%$ at 4 weeks, and a return to pretreatment baseline of $-0.44 \pm 3.1 \%$ at 8 weeks $)$ in response to thromboxane analog I-BOP $(0.25$ to $100 \mathrm{nmol} / \mathrm{L}$ ) [83]. Testosterone treatment also evidenced a significant increase in platelet $\mathrm{TxA}_{2}$ receptor density $(0.95 \pm 0.13$ at baseline, $1.51 \pm 0.22$ at 2 weeks, $2.10 \pm 0.43$ at 4 weeks, and $1.10 \pm 0.15$ at 8 weeks $)$ in response to thromboxane analog [ $\left.{ }^{125} \mathrm{I}\right] \mathrm{BOP}(80 \mu \mathrm{l}, 40,000 \mathrm{cpm})$, which correlated with the endogenous testosterone concentrations of the enrolled men [83]. Additionally, the same research group demonstrated in a cross-sectional case-control study that androgen receptor blockade, or the inhibition of testosterone production by surgical and/or medical castration of men with prostate cancer, downregulated the platelet $\mathrm{TxA}_{2}$ receptor density, and also reduced platelet aggregation [185]. These findings let the authors conclude that testosterone may act as a regulator of human platelet $\mathrm{TxA}_{2}$ receptors' expression, and this may contribute to the thrombogenicity of AAS.

Conversely, Khan et al. (2006) identified no influence of oxandrolone on ADP-induced platelet aggregation in short-term administration (intake of $10 \mathrm{mg}$ twice daily for 2 weeks) in 14 healthy subjects [171]. The lack of effect has been linked to platelets' $\mathrm{TxA}_{2}$ synthesis inhibition, induced by factor $\mathrm{V}$ and $\mathrm{X}$ elevation, as has been previously demonstrated by the same group of authors [186].

In a prospective randomized, double-blind, placebo-controlled study, the oral administration of $300 \mathrm{mg}$ of DHEA three times a day for 14 days in healthy men showed a delay in platelet aggregation when the platelets suspension was triggered by arachidonic acid. However, the study presents important limitations [168]. In elderly subjects, physiological doses (50 mg p.o. daily) and long-term administration (for 2 months) of DHEA induced an increase in platelet cGMP levels, as a marker of nitric oxide production, which may suggest a possible antiatherogenic effect of this steroid in physiological concentrations [187].

It has also been shown that testosterone and its reduced form dihydrotestosterone (DHT) have an inhibitory effect on platelet function in physiological concentrations. In a recent study assessing platelet reactivity by whole blood impedance aggregometry (in response to arachidonate, ADP, or collagen), and by using flow cytometry to measure platelet GP IIb/IIIa complex and P-selectin expression, a negative association between these parameters and the plasma concentrations of testosterone and DHT from older people was reported (the ex vivo part of the study). The data were later confirmed by the second, in vitro part of the study, which demonstrated that testosterone and DHT in progressively 
increased concentrations are able to inhibit platelet aggregation in response to collagen and arachidonic acid [188].

Substantial evidence documented the stimulatory influence of exogenous androgens on thrombopoiesis. In a large-scale retrospective study assessing the long-term benefits and side effects of the weak androgen danazol, prescribed for primary immune thrombocytopenia (ITP) in 103 patients, treatment with low to medium doses (200 or $300 \mathrm{mg}$ daily) for a median duration of therapy of 7 months resulted in an enhancement of platelet count from $220 \times 10^{9}(/ \mathrm{L})$ to $500 \times 10^{9}(/ \mathrm{L})$ [172]. Additionally, in a recent multicenter, randomized, open-label, phase 2 trial, combined oral therapy with danazol (200 mg twice daily, for 16 weeks) and all-trans retinoic acid was shown to be safe and effective in adult patients with ITP resistant to corticosteroid therapy [189]. The beneficial effect of danazol has also been shown in treating aplastic anemia and myelodysplastic syndromes (MDS), characterized by ineffective hematopoiesis and variable degrees of peripheral cytopenia [190-192]. A retrospective study has recently indicated that danazol in a median dose of $400 \mathrm{mg}$ per day, for a median follow-up of 12 months, could be considered as the first-line therapy in patients with MDS who cannot receive allogeneic stem cell transplantation [173].

There are also several cross-sectional studies indicating an enhancement of thrombopoiesis consecutive to long-term AAS abuse in bodybuilders, powerlifters, or athletes $[174,175,193]$. The platelet count appears to return to normal after at least 1 year of androgens withdrawal [193].

On the other hand, no effect on platelet count has been reported in healthy men subjected to testosterone undecanoate administration (1000 mg given in study weeks 0 , 6,12 , and 18) [176]. The lack of effect on platelet count is probably just a delay, as the hematopoietic effect of androgens does not seem to peak until 5 months [194].

In patients with polycystic ovary syndrome (PCOS) phenotypes 1 and 2 (linked with hyperandrogenemia), an increase in platelet-derived microparticles (PMPs) has been noted, PMPs appearing to be associated with atherosclerosis and also with a procoagulant profile $[195,196]$. The high mean platelet volume (MPV) has been recently suggested as a new indicator of cardiovascular disease risk. Studies on PCOS with elevated androgen levels tried to verify if any correlations between the levels of serum MPV and free testosterone could be evidenced, but findings are contradictory [197,198].

Overall, human studies bring more consistent evidence than experimental ones regarding the effects of exogenous androgens on platelet function and thrombopoiesis. Although several formulations, such as DHEA, or its sulfated form DHEAS, repeatedly indicated an inhibitory action on platelet function, most other types of androgens generally had a detrimental influence on platelet hemostatic activity and count, proven by both in vitro and ex vivo studies. Nevertheless, the scientific support for their prothrombotic effects is not compelling enough, and the present findings must be substantiated in further human clinical trials, other than classical observational studies on AAS abuse, or prospective ones conducted in patients subjected to prolonged androgen treatments for various diseases. Moreover, the intimate mechanisms need further clarification so as to provide a basis for bold conclusions.

Exogenous androgens lead to platelet activation and subsequent aggregation probably because of the concertedly operated nongenomic and genomic effects. Still far from being completely characterized, the main molecular mechanisms may be summarized in several distinct pathways (Figure 1), such as the following: enhancement of platelet cyclooxygenase activity $[161,199,200]$; increase in platelet $\mathrm{TxA}_{2}$ receptor density and $\mathrm{TxA}_{2}$ synthesis (usually determined in $\mathrm{TxB}_{2}$ form) [83,147,161-163], followed by an enhanced intracellular signaling through $\mathrm{TXA}_{2}$-receptor binding, which in turn results in an increased level of platelet free calcium [201]. This effect was identified to be mediated through AR and might be the result of the synthesis of new $\mathrm{TxA}_{2} / \mathrm{PGH}_{2}$ receptors $[165,166]$, also leading to an increase in intracellular AR affinity for testosterone [165,180,202]. Androgens are also able to increase PAF activity [146], to induce the diminution of platelet NO level (through the inhibition of the platelet NOS activity) [163], and to generate complementary 
processes on the endothelium that may lead to platelet activation, such as a reduction in NO release [112-114,124], the suppression of $\mathrm{PgI}_{2}$ production [203,204], and an increase in vascular $\mathrm{TxA}_{2}$ receptor density and endothelial TxA 2 synthesis $[147,205]$. Moreover, exogenous androgens have also been proven to increase the in vitro gene expression of the ADP receptor $\mathrm{P}_{2} \mathrm{Y}_{12}$ in human megakaryocytic DAMI cells [164], and to increase TxA receptor density and intracellular free calcium in HEL cells, which may be also linked to platelet activation [165-167].

\section{Conclusions}

In summary, the evidence presented herein leads to the conclusion that AAS excess may generate a prothrombotic state based on elevated platelet count, platelet agonists reactivity, and platelet activation with subsequent enhanced platelet aggregation. As noted, most of the reviewed human and animal studies revealed a stimulatory action of exogenous androgens on platelet function and count, whereas only a few others indicated a neutral, or even an inhibitory, effect. Regarding the influence of androgens in physiological doses on platelet function, researchers agreed on them having a beneficial effect. The heterogeneity of the findings results from imponderable factors, such as the various types of androgens used, the large variability in doses, time of intake, way of administration, or cycle of druguse in athletes, as well as the variable number of subjects included in studies, the hemostatic status of the human subjects prior to treatment, or even their individual susceptibility to androgen intake or therapy.

Even if there is a comprehensive body of evidence suggesting the existence of a proaggregant effect of exogenous androgens, the link between AAS abuse and thrombosis remains to be more clearly established. This causal relationship must also refer to the influence of androgen excess over the humoral system of coagulation and fibrinolysis, another subject of debate. The gathered data in this area suggest that AAS abuse induces an overactivation of the hemostatic system, with both procoagulant and fibrinolytic effects [104]. Depending on various exogenous or endogenous factors, at a certain moment the procoagulant action probably overcomes the fibrinolytic one. The coagulation abnormalities, especially when associated with increased platelet activity, may therefore lead to a thrombotic diathesis, which could explain the multitude of thromboembolic events reported so far in the AAS-abusing population.

Despite over fifty years of research on the thrombotic risk of androgens, the current state of knowledge in this regard is still scarce. Taking into account the fact that the prospective longitudinal studies in humans have unavoidable limitations, because of obvious ethical considerations, it is a certainty that at least more epidemiological studies with thrombosis outcome, and animal experiments with "real-life" AAS dosages are warranted, in order to elucidate the overall effect of supraphysiological androgens on hemostasis and to provide new compelling evidence for their claimed thrombogenic potential.

Author Contributions: Conceptualization, A.E.R.; project administration, A.E.R. and B.O.P.; writingoriginal draft preparation, A.E.R., A.M., S.E.V., M.O., C.B., C.C., A.-M.V., B.O.P., R.M., S..G. and L.Z.; writing-review and editing, A.E.R., A.M., S.E.V., M.O., C.C., A.-M.V., B.O.P. and L.Z.; visualization, A.E.R., B.O.P., A.-M.V., C.B., C.C., and L.Z.; supervision, A.-M.V., B.O.P. and L.Z. All authors have read and agreed to the published version of the manuscript.

Funding: This paper is partly supported by the Sectorial Operational Program Human Resources Development (SOPHRD), financed by the European Social Fund and the Romanian Government under the contract number POSDRU 141531.

Conflicts of Interest: The authors declare no conflict of interest. The funders had no role in the design of the study; in the collection, analyses, or interpretation of data; in the writing of the manuscript, or in the decision to publish the results. 


\section{References}

1. Kicman, A.T. Pharmacology of anabolic steroids. Br. J. Pharmacol. 2008, 154, 502-521. [CrossRef]

2. Kuhn, C.M. Anabolic steroids. Recent Prog. Horm. Res. 2002, 57, 411-434. [CrossRef] [PubMed]

3. Basaria, S.; Wahlstrom, J.T.; Dobs, A.S. Clinical review 138: Anabolic-androgenic steroid therapy in the treatment of chronic diseases. J. Clin. Endocrinol. Metab. 2001, 86, 5108-5117. [CrossRef] [PubMed]

4. Shahidi, N.T. A Review of the Chemistry, Biological Action, and Clinical Applications of Anabolic-Androgenic Steroids. Clin. Ther. 2001, 23, 1355-1390. [CrossRef]

5. Achar, S.; Rostamian, A.; Narayan, S.M. Cardiac and metabolic effects of anabolic-androgenic steroid abuse on lipids, blood pressure, left ventricular dimensions, and rhythm. Am. J. Cardiol. 2010, 106, 893-901. [CrossRef] [PubMed]

6. Wood, R.I. Anabolic steroids: A fatal attraction? J. Neuroendocrinol. 2006, 18, 227-228. [CrossRef] [PubMed]

7. Wood, R.I. Anabolic-androgenic steroid dependence? Insights from animals and humans. Front. Neuroendocrinol. 2008, 29, 490-506. [CrossRef]

8. Kanayama, G.; Hudson, J.I.; Pope, H.G.J. Long-term psychiatric and medical consequences of anabolic-androgenic steroid abuse: A looming public health concern? Drug Alcohol Depend. 2008, 98, 1-12. [CrossRef]

9. Pope, H.G.J.; Wood, R.I.; Rogol, A.; Nyberg, F.; Bowers, L.; Bhasin, S. Adverse health consequences of performance-enhancing drugs: An Endocrine Society scientific statement. Endocr. Rev. 2014, 35, 341-375. [CrossRef]

10. Sagoe, D.; Molde, H.; Andreassen, C.S.; Torsheim, T.; Pallesen, S. The global epidemiology of anabolic-androgenic steroid use: A meta-analysis and meta-regression analysis. Ann. Epidemiol. 2014, 24, 383-398. [CrossRef]

11. Hauger, L.E.; Westlye, L.T.; Bjørnebekk, A. Anabolic androgenic steroid dependence is associated with executive dysfunction Drug Alcohol. Depend. 2020, 208, 107874. [CrossRef] [PubMed]

12. Van Amsterdam, J.; Opperhuizen, A.; Hartgens, F. Adverse health effects of anabolic-androgenic steroids. Regul. Toxicol. Pharmacol. 2010, 57, 117-123. [CrossRef] [PubMed]

13. Bhasin, S.; Brito, J.P.; Cunningham, G.R.; Hayes, F.J.; Hodis, H.N.; Matsumoto, A.M.; Snyder, P.J.; Swerdloff, R.S.; Wu, F.C.; Yialamas, M.A. Testosterone Therapy in Men With Hypogonadism: An Endocrine Society Clinical Practice Guideline. J. Clin. Endocrinol. Metab. 2018, 103, 1715-1744. [CrossRef] [PubMed]

14. Kanayama, G.; Kaufman, M.J.; Pope, H.G.J. Public health impact of androgens. Curr. Opin. Endocrinol. Diabetes Obes. 2018, 25, 218-223. [CrossRef] [PubMed]

15. Mullen, C.; Whalley, B.J.; Schifano, F.; Baker, J.S. Anabolic androgenic steroid abuse in the United Kingdom: An update. Br. J. Pharmacol. 2020, 177, 2180-2198. [CrossRef] [PubMed]

16. Nieschlag, E. Doping with anabolic androgenic steroids (AAS): Adverse effects on non-reproductive organs and functions. Rev. Endocr. Metab. Disord. 2015. [CrossRef] [PubMed]

17. Hartgens, F.; Kuipers, H. Effects of androgenic-anabolic steroids in athletes. Sports Med. 2004, 34, 513-554. [CrossRef]

18. Melchert, R.B.; Welder, A.A. Cardiovascular effects of androgenic-anabolic steroids. Med. Sci. Sports Exerc. 1995, $27,1252-1262$. [CrossRef]

19. Fineschi, V.; Baroldi, G.; Monciotti, F.; Paglicci Reattelli, L.; Turillazzi, E. Anabolic steroid abuse and cardiac sudden death: A pathologic study. Arch. Pathol. Lab. Med. 2001, 125, 253-255.

20. McNutt, R.A.; Ferenchick, G.S.; Kirlin, P.C.; Hamlin, N.J. Acute myocardial infarction in a 22-year-old world class weight lifter using anabolic steroids. Am. J. Cardiol. 1988, 62, 164. [CrossRef]

21. Ferenchick, G.S.; Adelman, S. Myocardial infarction associated with anabolic steroid use in a previously healthy 37-year-old weight lifter. Am. Heart J. 1992, 124, 507-508. [CrossRef]

22. Flo, F.J.; Kanu, O.; Teleb, M.; Chen, Y.; Siddiqui, T. Anabolic androgenic steroid-induced acute myocardial infarction with multiorgan failure. Proc. (Bayl. Univ. Med. Cent.) 2018, 31, 334-336. [CrossRef] [PubMed]

23. Nieminen, M.S.; Rämö, M.P.; Viitasalo, M.; Heikkilä, P.; Karjalainen, J.; Mäntysaari, M.; Heikkilä, J. Serious cardiovascular side effects of large doses of anabolic steroids in weight lifters. Eur. Heart J. 1996, 17, 1576-1583. [CrossRef] [PubMed]

24. Dickerman, R.D.; Schaller, F.; Prather, I.; McConathy, W.J. Sudden cardiac death in a 20-year-old bodybuilder using anabolic steroids. Cardiology 1995, 86, 172-173. [CrossRef]

25. Winkler, U.H. Effects of androgens on haemostasis. Maturitas 1996, 24, 147-155. [CrossRef]

26. Ferenchick, G.S. Anabolic/androgenic steroid abuse and thrombosis: Is there a connection? Med. Hypotheses 1991, 35, 27-31. [CrossRef]

27. Dhar, R.; Stout, C.W.; Link, M.S.; Homoud, M.K.; Weinstock, J.; Estes, N.A.M., 3rd. Cardiovascular toxicities of performanceenhancing substances in sports. Mayo Clin. Proc. 2005, 80, 1307-1315. [CrossRef]

28. Christou, G.A.; Christou, K.A.; Nikas, D.N.; Goudevenos, J.A. Acute myocardial infarction in a young bodybuilder taking anabolic androgenic steroids: A case report and critical review of the literature. Eur. J. Prev. Cardiol. 2016. [CrossRef]

29. Ferenchick, G.; Schwartz, D.; Ball, M.; Schwartz, K. Androgenic-anabolic steroid abuse and platelet aggregation: A pilot study in weight lifters. Am. J. Med. Sci. 1992, 303, 78-82. [CrossRef]

30. Hourigan, L.A.; Rainbird, A.J.; Dooris, M. Intracoronary stenting for acute myocardial infarction (AMI) in a 24-year-old man using anabolic androgenic steroids. Aust. N. Z. J. Med. 1998, 28, 838-839. [CrossRef]

31. Ment, J.; Ludman, P.F. Coronary thrombus in a 23 year old anabolic steroid user. Heart 2002, 88, 342. [CrossRef] [PubMed] 
32. Tischer, K.-H.; Heyny-von Haussen, R.; Mall, G.; Doenecke, P. Coronary thrombosis and ectasia of coronary arteries after long-term use of anabolic steroids. Z. Kardiol. 2003, 92, 326-331. [CrossRef] [PubMed]

33. Güneş, Y.; Erbaş, C.; Okuyan, E.; Babalik, E.; Gürmen, T. Myocardial infarction with intracoronary thrombus induced by anabolic steroids. Anadolu Kardiyol. Derg. 2004, 4, 357-358. [PubMed]

34. Halvorsen, S.; Thorsby, P.M.; Haug, E. [Acute myocardial infarction in a young man who had been using androgenic anabolic steroids]. Tidsskr. Nor. Laegeforen. 2004, 124, 170-172.

35. Wysoczanski, M.; Rachko, M.; Bergmann, S.R. Acute myocardial infarction in a young man using anabolic steroids. Angiology 2008, 59, 376-378. [CrossRef]

36. Stergiopoulos, K.; Brennan, J.J.; Mathews, R.; Setaro, J.F.; Kort, S. Anabolic steroids, acute myocardial infarction and polycythemia: A case report and review of the literature. Vasc. Health Risk Manag. 2008, 4, 1475-1480. [CrossRef]

37. Ilhan, E.; Demirci, D.; Güvenç, T.S.; Calık, A.N. Acute myocardial infarction and renal infarction in a bodybuilder using anabolic steroids. Turk Kardiyol. Dern. Ars. 2010, 38, 275-278.

38. García-Esperón, C.; Hervás-García, J.V.; Jiménez-González, M.; Pérez de la Ossa-Herrero, N.; Gomis-Cortina, M.; Dorado-Bouix, L.; López-Cancio Martinez, E.; Castaño-Duque, C.H.; Millán-Torné, M.; Dávalos, A. Ingestion of anabolic steroids and ischaemic stroke. A clinical case report and review of the literature. Rev. Neurol. 2013, 56, 327-331.

39. Poorzand, H.; Jafarzadeh Esfehani, R.; Hosseinzadeh, P.; Vojdanparast, M. Acute myocardial infarction in a young male wrestler: A case report. ARYA Atheroscler. 2015, 11, 366-369.

40. Lehmann, S.; Thomas, A.; Schiwy-Bochat, K.-H.; Geyer, H.; Thevis, M.; Glenewinkel, F.; Rothschild, M.A.; Andresen-Streichert, H.; Juebner, M. Death after misuse of anabolic substances (clenbuterol, stanozolol and metandienone). Forensic Sci. Int. 2019, $303,109925$. [CrossRef]

41. Sonmez, E.; Turkdogan, K.A.; Yilmaz, C.; Kucukbuzcu, S.; Ozkan, A.; Sogutt, O. Chronic anabolic androgenic steroid usage associated with acute coronary syndrome in bodybuilder. Turk. J. Emerg. Med. 2016, 16, 35-37. [CrossRef] [PubMed]

42. Alrabadi, N.; Jarrah, M.I.; Alzoubi, K.H. Acute myocardial infarction with cardiogenic shock in a young physically active physician concurrently using the anabolic steroid sustanon: A case report. Biomed. Rep. 2020, 13, 14. [CrossRef] [PubMed]

43. Menkis, A.H.; Daniel, J.K.; McKenzie, F.N.; Novick, R.J.; Kostuk, W.J.; Pflugfelder, P.W. Cardiac Transplantation After Myocardial Infarction in a 24-Year-Old Bodybuilder Using Anabolic Steroids. Clin. J. Sport Med. 1991, 1, 138-140. [CrossRef]

44. Capezzuto, A.; Achilli, A.; Serra, N. Myocardial infarction in a 21-year-old body builder. Am. J. Cardiol. 1989, 63, 1539. [CrossRef]

45. Lyngberg, K.K. Myocardial infarction and death of a body builder after using anabolic steroids. Ugeskr. Laeger 1991, 153, 587-588.

46. Kennedy, M.C.; Lawrence, C. Anabolic steroid abuse and cardiac death. Med. J. Aust. 1993, 158, 346-348. [CrossRef]

47. Appleby, M.; Fisher, M.; Martin, M. Myocardial infarction, hyperkalaemia and ventricular tachycardia in a young male bodybuilder. Int. J. Cardiol. 1994, 44, 171-174. [CrossRef]

48. Huie, M.J. An acute myocardial infarction occurring in an anabolic steroid user. Med. Sci. Sports Exerc. 1994, $26,408-413$. [CrossRef]

49. Fisher, M.; Appleby, M.; Rittoo, D.; Cotter, L. Myocardial infarction with extensive intracoronary thrombus induced by anabolic steroids. Br. J. Clin. Pract. 1996, 50, 222-223.

50. Mewis, C.; Spyridopoulos, I.; Kühlkamp, V.; Seipel, L. Manifestation of severe coronary heart disease after anabolic drug abuse. Clin. Cardiol. 1996, 19, 153-155. [CrossRef]

51. McCarthy, K.; Tang, A.T.; Dalrymple-Hay, M.J.; Haw, M.P. Ventricular thrombosis and systemic embolism in bodybuilders: Etiology and management. Ann. Thorac. Surg. 2000, 70, 658-660. [CrossRef]

52. Frankle, M.A.; Eichberg, R.; Zachariah, S.B. Anabolic androgenic steroids and a stroke in an athlete: Case report. Arch. Phys. Med. Rehabil. 1988, 69, 632-633. [PubMed]

53. Hashmi, A.; Kim, P.; Ahmad, S.W.; Faucheux, J.; Gandikal, N. Superior Sagittal Venous Sinus Thrombosis in a Patient with Illicit Testosterone Use. Cureus 2019, 11, e5491. [CrossRef] [PubMed]

54. Mochizuki, R.M.; Richter, K.J. Cardiomyopathy and Cerebrovascular Accident Associated With Anabolic-Androgenic Steroid Use. Phys. Sportsmed. 1988, 16, 109-114. [CrossRef] [PubMed]

55. Laroche, G.P. Steroid anabolic drugs and arterial complications in an athlete-a case history. Angiology 1990, 41, 964-969. [CrossRef]

56. Jaillard, A.S.; Hommel, M.; Mallaret, M. Venous sinus thrombosis associated with androgens in a healthy young man. Stroke 1994, 25, 212-213. [CrossRef]

57. Sahraian, M.A.; Mottamedi, M.; Azimi, A.R.; Moghimi, B. Androgen-induced cerebral venous sinus thrombosis in a young body builder: Case report. BMC Neurol. 2004, 4, 22. [CrossRef]

58. Santamarina, R.D.; Besocke, A.G.; Romano, L.M.; Ioli, P.L.; Gonorazky, S.E. Ischemic stroke related to anabolic abuse. Clin. Neuropharmacol. 2008, 31, 80-85. [CrossRef]

59. Shimada, Y.; Yoritaka, A.; Tanaka, Y.; Miyamoto, N.; Ueno, Y.; Hattori, N.; Takao, U. Cerebral infarction in a young man using high-dose anabolic steroids. J. Stroke Cerebrovasc. Dis. Off. J. Natl. Stroke Assoc. 2012, 21, 906.e9-11. [CrossRef]

60. Sveinsson, O.; Herrman, L. Cortical venous thrombosis following exogenous androgen use for bodybuilding. BMJ Case Rep. 2013, 2013. [CrossRef]

61. Richard, S.; Lacour, J.-C.; Frotscher, B.; Enea, A.; Mione, G.; Ducrocq, X. Report of a recurrent cerebral venous thrombosis in a young athlete. BMC Neurol. 2014, 14, 182. [CrossRef] [PubMed] 
62. Falkenberg, M.; Karlsson, J.; Ortenwall, P. Peripheral arterial thrombosis in two young men using anabolic steroids. Eur. J. Vasc. Endovasc. Surg. Off. J. Eur. Soc. Vasc. Surg. 1997, 13, 223-226. [CrossRef]

63. Alvarado, R.G.; Liu, J.Y.; Zwolak, R.M. Danazol and limb-threatening arterial thrombosis: Two case reports. J. Vasc. Surg. 2001, 34, 1123-1126. [CrossRef] [PubMed]

64. McCulloch, N.A.; Abbas, J.R.; Simms, M.H. Multiple arterial thromboses associated with anabolic androgenic steroids. Clin. J. Sport Med. Off. J. Can. Acad. Sport Med. 2014, 24, 153-154. [CrossRef] [PubMed]

65. Gaede, J.T.; Montine, T.J. Massive pulmonary embolus and anabolic steroid abuse. JAMA 1992, 267, $2328-2329$.

66. Liljeqvist, S.; Helldén, A.; Bergman, U.; Söderberg, M. Pulmonary embolism associated with the use of anabolic steroids. Eur. J. Intern. Med. 2008, 19, 214-215. [CrossRef]

67. Choe, H.; Elfil, M.; DeSancho, M.T. Inherited antithrombin deficiency and anabolic steroids: A risky combination. Blood Coagul. Fibrinolysis Int. J. Haemost. Thromb. 2016, 27, 717-719. [CrossRef]

68. Alhadad, A.; Acosta, S.; Sarabi, L.; Kölbel, T. Pulmonary embolism associated with protein C deficiency and abuse of anabolicandrogen steroids. Clin. Appl. Thromb. Off. J. Int. Acad. Clin. Appl. Thromb. 2010, 16, 228-231. [CrossRef]

69. Damasceno, E.F.; Neto, A.M.; Damasceno, N.A.P.; Horowitz, S.A.P.; de Moraes Junior, H.V. Branch retinal vein occlusion and anabolic steroids abuse in young bodybuilders. Acta Ophthalmol. 2009, 87, 580-581. [CrossRef]

70. Ammatuna, E.; Nijziel, M.R. Polycythemia and renal infarction in a bodybuilder. QJM 2014, 107, 661-662. [CrossRef]

71. Colburn, S.; Childers, W.K.; Chacon, A.; Swailes, A.; Ahmed, F.M.; Sahi, R. The cost of seeking an edge: Recurrent renal infarction in setting of recreational use of anabolic steroids. Ann. Med. Surg. 2017, 14, 25-28. [CrossRef] [PubMed]

72. Luke, J.L.; Farb, A.; Virmani, R.; Sample, R.H. Sudden cardiac death during exercise in a weight lifter using anabolic androgenic steroids: Pathological and toxicological findings. J. Forensic. Sci. 1990, 35, 1441-1447. [CrossRef] [PubMed]

73. Hausmann, R.; Hammer, S.; Betz, P. Performance enhancing drugs (doping agents) and sudden death-a case report and review of the literature. Int. J. Legal Med. 1998, 111, 261-264. [CrossRef] [PubMed]

74. Di Paolo, M.; Agozzino, M.; Toni, C.; Luciani, A.B.; Molendini, L.; Scaglione, M.; Inzani, F.; Pasotti, M.; Buzzi, F.; Arbustini, E. Sudden anabolic steroid abuse-related death in athletes. Int. J. Cardiol. 2007, 114, 114-117. [CrossRef] [PubMed]

75. Fineschi, V.; Riezzo, I.; Centini, F.; Silingardi, E.; Licata, M.; Beduschi, G.; Karch, S.B. Sudden cardiac death during anabolic steroid abuse: Morphologic and toxicologic findings in two fatal cases of bodybuilders. Int. J. Legal Med. 2007, 121, 48-53. [CrossRef] [PubMed]

76. Montisci, M.; El Mazloum, R.; Cecchetto, G.; Terranova, C.; Ferrara, S.D.; Thiene, G.; Basso, C. Anabolic androgenic steroids abuse and cardiac death in athletes: Morphological and toxicological findings in four fatal cases. Forensic Sci. Int. 2012, 217, e13-e18. [CrossRef]

77. Frati, P.; Busardò, F.P.; Cipolloni, L.; De Dominicis, E.; Fineschi, V. Anabolic Androgenic Steroid (AAS) related deaths: Autoptic, histopathological and toxicological findings. Curr. Neuropharmacol. 2015, 13, 146-159. [CrossRef]

78. Hernández-Guerra, A.I.; Tapia, J.; Menéndez-Quintanal, L.M.; Lucena, J.S. Sudden cardiac death in anabolic androgenic steroids abuse: Case report and literature review. Forensic Sci. Res. 2019, 4, 267-273. [CrossRef]

79. Pärssinen, M.; Kujala, U.; Vartiainen, E.; Sarna, S.; Seppälä, T. Increased premature mortality of competitive powerlifters suspected to have used anabolic agents. Int. J. Sports Med. 2000, 21, 225-227. [CrossRef]

80. Thiblin, I.; Garmo, H.; Garle, M.; Holmberg, L.; Byberg, L.; Michaëlsson, K.; Gedeborg, R. Anabolic steroids and cardiovascular risk: A national population-based cohort study. Drug Alcohol Depend. 2015, 152, 87-92. [CrossRef]

81. Chu, K.; Kang, D.W.; Kim, D.E.; Roh, J.K. Cerebral venous thrombosis associated with tentorial subdural hematoma during oxymetholone therapy. J. Neurol. Sci. 2001, 185, 27-30. [CrossRef]

82. Shiozawa, Z.; Yamada, H.; Mabuchi, C.; Hotta, T.; Saito, M.; Sobue, I.; Huang, Y.P. Superior sagittal sinus thrombosis associated with androgen therapy for hypoplastic anemia. Ann. Neurol. 1982, 12, 578-580. [CrossRef] [PubMed]

83. Ajayi, A.A.; Mathur, R.; Halushka, P.V. Testosterone increases human platelet thromboxane A2 receptor density and aggregation responses. Circulation 1995, 91, 2742-2747. [CrossRef] [PubMed]

84. Nagelberg, S.B.; Laue, L.; Loriaux, D.L.; Liu, L.; Sherins, R.J. Cerebrovascular accident associated with testosterone therapy in a 21-year-old hypogonadal man. N. Engl. J. Med. 1986, 314, 649-650. [PubMed]

85. Xu, L.; Freeman, G.; Cowling, B.J.; Schooling, C.M. Testosterone therapy and cardiovascular events among men: A systematic review and meta-analysis of placebo-controlled randomized trials. BMC Med. 2013, 11, 108. [CrossRef]

86. Martinez, C.; Suissa, S.; Rietbrock, S.; Katholing, A.; Freedman, B.; Cohen, A.T.; Handelsman, D.J. Testosterone treatment and risk of venous thromboembolism: Population based case-control study. BMJ 2016, 355, i5968. [CrossRef] [PubMed]

87. Morgentaler, A.; Miner, M.M.; Caliber, M.; Guay, A.T.; Khera, M.; Traish, A.M. Testosterone Therapy and Cardiovascular Risk: Advances and Controversies. Mayo Clin. Proc. 2015, 90, 224-251. [CrossRef]

88. Kloner, R.A.; Carson, C., 3rd; Dobs, A.; Kopecky, S.; Mohler, E.R., 3rd. Testosterone and Cardiovascular Disease. J. Am. Coll. Cardiol. 2016, 67, 545-557. [CrossRef]

89. Corona, G.; Maseroli, E.; Rastrelli, G.; Isidori, A.M.; Sforza, A.; Mannucci, E.; Maggi, M. Cardiovascular risk associated with testosterone-boosting medications: A systematic review and meta-analysis. Expert Opin. Drug Saf. 2014, 13, 1327-1351. [CrossRef]

90. Houghton, D.E.; Alsawas, M.; Barrioneuvo, P.; Tello, M.; Farah, W.; Beuschel, B.; Prokop, L.J.; Layton, J.B.; Murad, M.H.; Moll, S. Testosterone therapy and venous thromboembolism: A systematic review and meta-analysis. Thromb. Res. 2018, 172, 94-103. [CrossRef] 
91. Pawlowitzki, I.H.; Diekstall, P.; Miny, P.; Balleisen, L. Abnormal platelet function in Kallmann syndrome. Lancet 1986, 2, 166. [CrossRef]

92. Iijima, M.; Shigehara, K.; Sugimoto, K.; Kouji, I.; Fukushima, M.; Maeda, Y.; Konaka, H.; Mizokami, A.; Koh, E.; Namiki, M. Myelodysplastic syndrome treated effectively with testosterone enanthate. Int. J. Urol. Off. J. Jpn. Urol. Assoc. 2011, 18, 469-471. [CrossRef] [PubMed]

93. Uzunova, A.; Ramey, E.; Ramwell, P.W. Effect of testosterone, sex and age on experimentally induced arterial thrombosis. Nature 1976, 261, 712-713. [CrossRef] [PubMed]

94. Uzunova, A.D.; Ramey, E.R.; Ramwell, P.W. Arachidonate-induced thrombosis in mice: Effects of gender or testosterone and estradiol administration. Prostaglandins 1977, 13, 995-1002. [CrossRef]

95. Uzunova, A.D.; Ramey, E.R.; Ramwell, P.W. Gonadal hormones and pathogenesis of occlusive arterial thrombosis. Am. J. Physiol. 1978, 234, H454-H459. [CrossRef]

96. Rosenblum, W.I.; el-Sabban, F.; Nelson, G.H.; Allison, T.B. Effects in mice of testosterone and dihydrotestosterone on platelet aggregation in injured arterioles and ex vivo. Thromb. Res. 1987, 45, 719-728. [CrossRef]

97. Li, S.; Li, X.; Li, J.; Deng, X.; Li, Y.; Cong, Y. Experimental arterial thrombosis regulated by androgen and its receptor via modulation of platelet activation. Thromb. Res. 2007, 121, 127-134. [CrossRef]

98. Chan, M.Y.; Andreotti, F.; Becker, R.C. Hypercoagulable states in cardiovascular disease. Circulation 2008, 118, $2286-2297$. [CrossRef]

99. Campo, G.; Valgimigli, M.; Ferraresi, P.; Malagutti, P.; Baroni, M.; Arcozzi, C.; Gemmati, D.; Percoco, G.; Parrinello, G.; Ferrari, R.; et al. Tissue factor and coagulation factor VII levels during acute myocardial infarction: Association with genotype and adverse events. Arterioscler. Thromb. Vasc. Biol. 2006, 26, 2800-2806. [CrossRef]

100. Doggen, C.J.M.; Rosendaal, F.R.; Meijers, J.C.M. Levels of intrinsic coagulation factors and the risk of myocardial infarction among men: Opposite and synergistic effects of factors XI and XII. Blood 2006, 108, 4045-4051. [CrossRef]

101. Koenig, W. Haemostatic risk factors for cardiovascular diseases. Eur. Heart J. 1998, 19 (Suppl. C), C39-C43. [PubMed]

102. Juhan-Vague, I.; Pyke, S.D.; Alessi, M.C.; Jespersen, J.; Haverkate, F.; Thompson, S.G. Fibrinolytic factors and the risk of myocardial infarction or sudden death in patients with angina pectoris. ECAT Study Group. European Concerted Action on Thrombosis and Disabilities. Circulation 1996, 94, 2057-2063. [CrossRef] [PubMed]

103. Glueck, C.J.; Friedman, J.; Hafeez, A.; Hassan, A.; Wang, P. Testosterone, thrombophilia, thrombosis. Blood Coagul. Fibrinolysis Int. J. Haemost. Thromb. 2014, 25, 683-687. [CrossRef] [PubMed]

104. Chang, S.; Münster, A.-M.B.; Gram, J.; Sidelmann, J.J. Anabolic Androgenic Steroid Abuse: The Effects on Thrombosis Risk, Coagulation, and Fibrinolysis. Semin. Thromb. Hemost. 2018, 44, 734-746. [CrossRef]

105. Lippi, G.; Banfi, G. Doping and thrombosis in sports. Semin. Thromb. Hemost. 2011, 37, 918-928. [CrossRef]

106. Király, C.L. Androgenic-anabolic steroid effects on serum and skin surface lipids, on red cells, and on liver enzymes. Int. J. Sports Med. 1988, 9, 249-252. [CrossRef]

107. Ghorbanihaghjo, A.; Argani, H.; Rohbaninoubar, M.; Rashtchizadeh, N. Effect of Nandrolone Decanoate on serum lipoprotein (a) and its isoforms in hemodialysis patients. Lipids Health Dis. 2004, 3, 16. [CrossRef]

108. Teruel, J.L.; Lasuncion, M.A.; Rivera, M.; Aguilera, A.; Ortega, H.; Tato, A.; Marcen, R.; Ortuño, J. Nandrolone decanoate reduces serum lipoprotein(a) concentrations in hemodialysis patients. Am. J. Kidney Dis. Off. J. Natl. Kidney Found. 1997, $29,569-575$. [CrossRef]

109. Rosca, A.E.; Stancu, C.S.; Badiu, C.; Popescu, B.O.; Mirica, R.; Căruntu, C.; Gologan, S.; Voiculescu, S.E.; Zagrean, A.-M. Lipid Profile Changes Induced by Chronic Administration of Anabolic Androgenic Steroids and Taurine in Rats. Medicina (Kaunas) 2019, 55, 540. [CrossRef]

110. Graham, M.R.; Grace, F.M.; Boobier, W.; Hullin, D.; Kicman, A.; Cowan, D.; Davies, B.; Baker, J.S. Homocysteine induced cardiovascular events: A consequence of long term anabolic-androgenic steroid (AAS) abuse. Br. J. Sports Med. 2006, 40, 644-648. [CrossRef]

111. Vanberg, P.; Atar, D. Androgenic anabolic steroid abuse and the cardiovascular system. Handb. Exp. Pharmacol. 2010, 411-457. [CrossRef]

112. dos Santos, M.A.P.; de Oliveira, C.V.C.; Silva, A.S. Adverse cardiovascular effects from the use of anabolic-androgenic steroids as ergogenic resources. Subst. Use Misuse 2014, 49, 1132-1137. [CrossRef] [PubMed]

113. Skogastierna, C.; Hotzen, M.; Rane, A.; Ekström, L. A supraphysiological dose of testosterone induces nitric oxide production and oxidative stress. Eur. J. Prev. Cardiol. 2014, 21, 1049-1054. [CrossRef] [PubMed]

114. Sun, M.; Shen, W.; Zhong, M.; Wu, P.; Chen, H.; Lu, A. Nandrolone attenuates aortic adaptation to exercise in rats. Cardiovasc. Res. 2013, 97, 686-695. [CrossRef] [PubMed]

115. Roşca, A.E.; Stoian, I.; Badiu, C.; Gaman, L.; Popescu, B.O.; Iosif, L.; Mirica, R.; Tivig, I.C.; Stancu, C.S.; Căruntu, C.; et al. Impact of chronic administration of anabolic androgenic steroids and taurine on blood pressure in rats. Braz. J. Med. Biol. Res. Rev. Bras. Pesqui. Med. Biol. 2016, 49, e5116. [CrossRef]

116. O'Connell, B.J.; Genest, J.J. High-density lipoproteins and endothelial function. Circulation 2001, 104, 1978-1983. [CrossRef]

117. Van der Stoep, M.; Korporaal, S.J.A.; Van Eck, M. High-density lipoprotein as a modulator of platelet and coagulation responses. Cardiovasc. Res. 2014, 103, 362-371. [CrossRef]

118. Baron, A.D. Vascular reactivity. Am. J. Cardiol. 1999, 84, 25J-27J. [CrossRef] 
119. Baskurt, O.K.; Meiselman, H.J. Iatrogenic hyperviscosity and thrombosis. Semin. Thromb. Hemost. 2012, 38, 854-864. [CrossRef]

120. Chan, L.W.; Luo, X.P.; Ni, H.C.; Shi, H.M.; Liu, L.; Wen, Z.C.; Gu, X.Y.; Qiao, J.; Li, J. High levels of LDL-C combined with low levels of HDL-C further increase platelet activation in hypercholesterolemic patients. Braz. J. Med. Biol. Res. Rev. Bras. Pesqui. Med. Biol. 2015, 48, 167-173. [CrossRef]

121. Fowler, B. Homocystein-an independent risk factor for cardiovascular and thrombotic diseases. Ther. Umsch. 2005, 62, 641-646. [CrossRef] [PubMed]

122. Kim, Y.-W.; West, X.Z.; Byzova, T.V. Inflammation and oxidative stress in angiogenesis and vascular disease. J. Mol. Med. 2013, 91, 323-328. [CrossRef] [PubMed]

123. Aird, W.C. Endothelium and haemostasis. Hamostaseologie 2015, 35, 11-16. [CrossRef] [PubMed]

124. Lei, J.; Vodovotz, Y.; Tzeng, E.; Billiar, T.R. Nitric oxide, a protective molecule in the cardiovascular system. Nitric Oxide Biol. Chem. 2013, 35, 175-185. [CrossRef]

125. Baszczuk, A.; Kopczyński, Z.; Thielemann, A. Endothelial dysfunction in patients with primary hypertension and hyperhomocysteinemia. Postepy Hig. Med. Dosw. (Online) 2014, 68, 91-100. [CrossRef]

126. Sudano, I.; Roas, S.; Noll, G. Vascular abnormalities in essential hypertension. Curr. Pharm. Des. 2011, 17, 3039-3044. [CrossRef]

127. Fraer, M.; Kilic, F. Serotonin: A different player in hypertension-associated thrombosis. Hypertens. (Dallas Tex. 1979) 2015, 65, 942-948. [CrossRef]

128. Higgins, J.P.; Heshmat, A.; Higgins, C.L. Androgen abuse and increased cardiac risk. South. Med. J. 2012, 105, 670-674. [CrossRef]

129. Nascimento, J.H.M.; Medei, E. Cardiac effects of anabolic steroids: Hypertrophy, ischemia and electrical remodelling as potential triggers of sudden death. Mini Rev. Med. Chem. 2011, 11, 425-429. [CrossRef]

130. Riezzo, I.; De Carlo, D.; Neri, M.; Nieddu, A.; Turillazzi, E.; Fineschi, V. Heart disease induced by AAS abuse, using experimental mice/rats models and the role of exercise-induced cardiotoxicity. Mini Rev. Med. Chem. 2011, 11, 409-424. [CrossRef]

131. Torrisi, M.; Pennisi, G.; Russo, I.; Amico, F.; Esposito, M.; Liberto, A.; Cocimano, G.; Salerno, M.; Li Rosi, G.; Di Nunno, N.; et al. Sudden Cardiac Death in Anabolic-Androgenic Steroid Users: A Literature Review. Medicina (Kaunas) 2020, 56, 587. [CrossRef] [PubMed]

132. Middlebrook, I.; Schoener, B. Anabolic Steroid Toxicity; Treasure Island (FL): StatPearls Publishing (LLC): Florida, FL, USA, $2020 ;$ pp. 1-30.

133. Nieswandt, B.; Pleines, I.; Bender, M. Platelet adhesion and activation mechanisms in arterial thrombosis and ischaemic stroke. J. Thromb. Haemost. 2011, 9 (Suppl. 1), 92-104. [CrossRef] [PubMed]

134. Jennings, L.K. Mechanisms of platelet activation: Need for new strategies to protect against platelet-mediated atherothrombosis. Thromb. Haemost. 2009, 102, 248-257. [CrossRef] [PubMed]

135. Marder, V.J.; Aird, W.C.; Bennett, J.S.; Schulman, S.; White, G.C., II. Hemostasis and Thrombosis: Basic Principles and Clinical Practice; Lippincott Williams \& Wilkins (LWW): Philadelphia, PA, USA, 2012; pp. 402-403.

136. Marder, V.J.; Aird, W.C.; Bennett, J.S.; Schulman, S.; White, G.C., II. Hemostasis and Thrombosis: Basic Principles and Clinical Practice; Lippincott Williams \& Wilkins (LWW): Philadelphia, PA, USA, 2012; p. 428. ISBN 978-1-60-831906-0.

137. Marder, V.J.; Aird, W.C.; Bennett, J.S.; Schulman, S.; White, G.C., II. Hemostasis and Thrombosis: Basic Principles and Clinical Practice; Lippincott Williams \& Wilkins (LWW): Philadelphia, PA, USA, 2012; pp. 449-461. ISBN 978-1-60-831906-0.

138. Nurden, A.T.; Nurden, P. Inherited disorders of platelet function: Selected updates. J. Thromb. Haemost. 2015, 13, S2-S9. [CrossRef]

139. Kendall, D. Overview of phosphoinositide hydrolysis. Curr. Protoc. Pharmacol. 2001. [CrossRef]

140. Estevez, B.; Du, X. New concepts and mechanisms of platelet activation signaling. Physiology 2017, 32, 162-177. [CrossRef]

141. Gachet, C.; Hechler, B. Platelet Purinergic Receptors in Thrombosis and Inflammation. Hamostaseologie 2020, 40, 145-152. [CrossRef]

142. Gkaliagkousi, E.; Ritter, J.; Ferro, A. Platelet-derived nitric oxide signaling and regulation. Circ. Res. 2007, 101, 654-662. [CrossRef]

143. Schwarz, U.R.; Walter, U.; Eigenthaler, M. Taming platelets with cyclic nucleotides. Biochem. Pharmacol. 2001, 62, 1153-1161. [CrossRef]

144. Johnson, M.; Ramey, E.; Ramwell, P.W. Androgen-mediated sensitivity in platelet aggregation. Am. J. Physiol. 1977, 232 , H381-H385. [CrossRef]

145. Skjaerlund, J.M.; Deitemeyer, D.; Yunker, R.L.; Subbiah, M.T. Effect of testosterone and oxandrolone on thrombocyte aggregation and synthesis of prostaglandins in thrombocytes and aorta of atherosclerosis-susceptible pigeons. Andrologia 1983, 15, 57-61. [CrossRef] [PubMed]

146. Muguruma, K.; Komatz, Y.; Ikeda, M.; Sugimoto, T.; Saito, K. Platelet-activating factor (PAF) in male reproductive organs of guinea pigs and rats: Effect of androgen on PAF in seminal vesicles. Biol. Reprod. 1993, 48, 386-392. [CrossRef] [PubMed]

147. Matsuda, K.; Ruff, A.; Morinelli, T.A.; Mathur, R.S.; Halushka, P.V. Testosterone increases thromboxane A2 receptor density and responsiveness in rat aortas and platelets. Am. J. Physiol. 1994, 267, H887-H893. [CrossRef] [PubMed]

148. Bednarek-Tupikowska, G.; Gosk, I.; Szuba, A.; Bohdanowicz-Pawlak, A.; Kosowska, B.; Bidzińska, B.; Milewicz, A. Influence of dehydroepiandrosterone on platelet aggregation, superoxide dismutase activity and serum lipid peroxide concentrations in rabbits with induced hypercholesterolemia. Med. Sci. Monit. Int. Med. J. Exp. Clin. Res. 2000, 6, 40-45.

149. Aydilek, N.; Aksakal, M. Effects of testosterone on lipid peroxidation, lipid profiles and some coagulation parameters in rabbits. J. Vet. Med. A. Physiol. Pathol. Clin. Med. 2005, 52, 436-439. [CrossRef] 
150. Sullivan, P.S.; Jackson, C.W.; McDonald, T.P. Castration decreases thrombocytopoiesis and testosterone restores platelet production in castrated BALB/c mice: Evidence that testosterone acts on a bipotential hematopoietic precursor cell. J. Lab. Clin. Med. 1995, 125, 326-333.

151. Alhawiti, N.M.; Alqahtani, S.A. Chronic testosterone administration improves cardiac contractility and has a beneficial effect on the haemostatic system by enhancing fibrinolytic activity and inducing hypocoagulation in healthy rats. Arch. Physiol. Biochem. 2018, 125, 311-320. [CrossRef]

152. Roşca, A.E.; Badiu, C.; Uscătescu, V.; Stoian, I.; Mirică, R.; Braga, R.I.; Pavel, B.; Zăgrean, L. Influence of chronic administration of anabolic androgenic steroids and taurine on haemostasis profile in rats: A thrombelastographic study. Blood Coagul. Fibrinolysis Int. J. Haemost. Thromb. 2013, 24, 256-260. [CrossRef]

153. Rosca, A.; Badiu, C.; Uscatescu, V.; Mirica, R.; Braga, R.; Pavel, B.; Zagrean, L. Effect of chronic administration of anabolic androgenic steroids and taurine on platelet agregation in rats. Acta Endocrinol. 2013, 9, 33-39. [CrossRef]

154. Schafer, A.I. The hypercoagulable states. Ann. Intern. Med. 1985, 102, 814-828. [CrossRef]

155. Appleby, N.; Angelov, D. Clinical and laboratory assessment of a patient with thrombocytosis. Br. J. Hosp. Med. 2017, 78, 558-564. [CrossRef] [PubMed]

156. Li, S.; Li, X.; Li, J.; Deng, X.; Li, Y. Inhibition of oxidative-stress-induced platelet aggregation by androgen at physiological levels via its receptor is associated with the reduction of thromboxane A2 release from platelets. Steroids 2007, 72, 875-880. [CrossRef] [PubMed]

157. Cutini, P.H.; Campelo, A.E.; Agriello, E.; Sandoval, M.J.; Rauschemberger, M.B.; Massheimer, V.L. The role of sex steroids on cellular events involved in vascular disease. J. Steroid Biochem. Mol. Biol. 2012, 132, 322-330. [CrossRef] [PubMed]

158. Campelo, A.E.; Cutini, P.H.; Massheimer, V.L. Cellular actions of testosterone in vascular cells: Mechanism independent of aromatization to estradiol. Steroids 2012, 77, 1033-1040. [CrossRef] [PubMed]

159. Campelo, A.E.; Cutini, P.H.; Massheimer, V.L. Testosterone modulates platelet aggregation and endothelial cell growth through nitric oxide pathway. J. Endocrinol. 2012, 213, 77-87. [CrossRef] [PubMed]

160. Johnson, M.; Ramey, E.; Ramwell, P.W. Sex and age differences in human platelet aggregation. Nature 1975, $253,355-357$. [CrossRef] [PubMed]

161. Pilo, R.; Aharony, D.; Raz, A. Testosterone potentiation of ionophore and ADP induced platelet aggregation: Relationship to arachidonic acid metabolism. Thromb. Haemost. 1981, 46, 538-542. [CrossRef]

162. Togna, G.I.; Togna, A.R.; Graziani, M.; Franconi, M. Testosterone and cocaine: Vascular toxicity of their concomitant abuse. Thromb. Res. 2003, 109, 195-201. [CrossRef]

163. Banerjee, D.; Mazumder, S.; Bhattacharya, S.; Sinha, A.K. The sex specific effects of extraneous testosterone on ADP induced platelet aggregation in platelet-rich plasma from male and female subjects. Int. J. Lab. Hematol. 2014, 36, e74-e77. [CrossRef]

164. Lee, S.; Kwon, J.; Cho, S.; Jarrar, Y.B.; Shin, J. Effects of testosterone and $17 \mathrm{~b}$-oestradiol on expression of the G protein-coupled receptor P2Y12 in megakaryocytic DAMI cells. Platelets. 2012, 23, 579-585. [CrossRef]

165. Matsuda, K.; Mathur, R.S.; Duzic, E.; Halushka, P.V. Androgen regulation of thromboxane A2/prostaglandin H2 receptor expression in human erythroleukemia cells. Am. J. Physiol. 1993, 265, E928-E934. [CrossRef] [PubMed]

166. Halushka, P.V.; Masuda, A.; Matsuda, K. The Gordon Wilson Lecture. Regulation of thromboxane A2 receptors by testosterone: Implications for steroid abuse and cardiovascular disease. Trans. Am. Clin. Climatol. Assoc. 1994, 105, 95-103. [PubMed]

167. Zucker, T.P.; Higashiura, K.; Mathur, R.S.; Halushka, P.V. Androstenedione increases thromboxane A2 receptors in human erythroleukemia cells. Life Sci. 1996, 58, 683-690. [CrossRef]

168. Jesse, R.L.; Loesser, K.; Eich, D.M.; Qian, Y.Z.; Hess, M.L.; Nestler, J.E. Dehydroepiandrosterone inhibits human platelet aggregation in vitro and in vivo. Ann. N. Y. Acad. Sci. 1995, 774, 281-290. [CrossRef] [PubMed]

169. Bertoni, A.; Rastoldo, A.; Sarasso, C.; Di, C.; Sampietro, S.; Nalin, M.; Bagarotti, A.; Sinigaglia, F. Dehydroepiandrosterone-sulfate inhibits thrombin-induced platelet aggregation. Steroids 2012, 77, 260-268. [CrossRef]

170. Muñoz, Y.C.; Gomez, G.I.; Moreno, M.; Solis, C.L.; Valladares, L.E.; Velarde, V. Dehydroepiandrosterone prevents the aggregation of platelets obtained from postmenopausal women with type 2 diabetes mellitus through the activation of the PKC/eNOS/NO pathway. Horm. Metab. Res. Horm. Stoffwechselforsch. Horm. Metab. 2012, 44, 625-631. [CrossRef]

171. Kahn, N.N.; Sinha, A.K.; Spungen, A.M.; Bauman, W.A. Effects of oxandrolone, an anabolic steroid, on hemostasis. Am. J. Hematol. 2006, 81, 95-100. [CrossRef]

172. Liu, W.; Gu, X.; Fu, R.; Li, Y.; Lv, M.; Sun, T.; Lv, C.; Liu, X.; Xue, F.; Zhang, L.; et al. The Effect of Danazol in Primary Immune Thrombocytopenia: An Analysis of a Large Cohort from a Single Center in China. Clin. Appl. Thromb. Off. J. Int. Acad. Clin. Appl. Thromb. 2016, 22, 727-733. [CrossRef]

173. Colunga-Pedraza, P.R.; Colunga-Pedraza, J.E.; Garza-Ledezma, M.A.; Jaime-Pérez, J.C.; Cantú-Rodríguez, O.G.; GutiérrezAguirre, C.H.; Rendón-Ramírez, E.J.; López-García, Y.K.; Lozano-Morales, R.E.; Gómez-De León, A.; et al. Danazol as First-Line Therapy for Myelodysplastic Syndrome. Clin. Lymphoma. Myeloma Leuk. 2018, 18, e109-e113. [CrossRef]

174. Ansell, J.E.; Tiarks, C.; Fairchild, V.K. Coagulation abnormalities associated with the use of anabolic steroids. Am. Heart J. 1993, 125, 367-371. [CrossRef]

175. Severo, C.B.; Ribeiro, J.P.; Umpierre, D.; Da Silveira, A.D.; Padilha, M.C.; De Aquino Neto, F.R.; Stein, R. Increased atherothrombotic markers and endothelial dysfunction in steroid users. Eur. J. Prev. Cardiol. 2013, 20, 195-201. [CrossRef] 
176. Zitzmann, M.; Junker, R.; Kamischke, A.; Nieschlag, E. Contraceptive Steroids Influence the Hemostatic Activation State in Healthy Men. J. Androl. 2002, 23, 503-511. [PubMed]

177. Khetawat, G.; Faraday, N.; Nealen, M.L.; Vijayan, K.V.; Bolton, E.; Noga, S.J.; Bray, P.F. Human megakaryocytes and platelets contain the estrogen receptor beta and androgen receptor (AR): Testosterone regulates AR expression. Blood 2000, 95, 2289-2296. [CrossRef] [PubMed]

178. Sarabia, S.F.; Raya, J.L.; Hoogeveen, R.C.; Bray, P.F. Human platelets differentially concentrate estradiol, estrone and testosterone. J. Thromb. Haemost. 2008, 6, 703-705. [CrossRef] [PubMed]

179. Nealen, M.L.; Vijayan, K.V.; Bolton, E.; Bray, P.F. Human platelets contain a glycosylated estrogen receptor beta. Circ. Res. 2001, 88, 438-442. [CrossRef] [PubMed]

180. Cabeza, M.; Flores, M.; Bratoeff, E.; de la Peña, A.; Mendez, E.; Ceballos, G. Intracellular Ca2+ stimulates the binding to androgen receptors in platelets. Steroids 2004, 69, 767-772. [CrossRef]

181. Milewich, L.; Whisenant, M.G. Metabolism of androstenedione by human platelets: A source of potent androgens. J. Clin. Endocrinol. Metab. 1982, 54, 969-974. [CrossRef]

182. Gnatenko, D.V.; Cupit, L.D.; Huang, E.C.; Dhundale, A.; Perrotta, P.L.; Bahou, W.F. Platelets express steroidogenic 17beta-hydroxysteroid dehydrogenases. Distinct profiles predict the essential thrombocythemic phenotype. Thromb. Haemost. 2005, 94, 412-421. [CrossRef]

183. Garrido, A.; Munoz, Y.; Sierralta, W.; Valladares, L. Metabolism of dehydroepiandrosterone sulfate and estrone-sulfate by human platelets. Physiol. Res. 2012, 61, 381-388. [CrossRef]

184. Zaslavsky, A.B.; Gloeckner-Kalousek, A.; Adams, M.; Putluri, N.; Venghatakrishnan, H.; Li, H.; Morgan, T.M.; Feng, F.Y.; Tewari, M.; Sreekumar, A.; et al. Platelet-Synthesized Testosterone in Men with Prostate Cancer Induces Androgen Receptor Signaling. Neoplasia 2015, 17, 490-496. [CrossRef]

185. Ajayi, A.A.L.; Halushka, P.V. Castration reduces platelet thromboxane A 2 receptor density and aggregability. QJM 2005, 349-356. [CrossRef] [PubMed]

186. Sinha, A.K.; Rao, A.K.; Willis, J.; Colman, R.W. Inhibition of thromboxane A2 synthesis in human platelets by coagulation factor Xa. Proc. Natl. Acad. Sci. USA 1983, 80, 6086-6090. [CrossRef] [PubMed]

187. Martina, V.; Benso, A.; Gigliardi, V.R.; Masha, A.; Origlia, C. Short-term dehydroepiandrosterone treatment increases platelet cGMP production in elderly male subjects. Clin. Endocrinol. 2006, 260-264. [CrossRef] [PubMed]

188. Karolczak, K.; Konieczna, L.; Kostka, T.; Witas, P.J.; Soltysik, B.; Baczek, T.; Watala, C. Testosterone and dihydrotestosterone reduce platelet activation and reactivity in older men and women. Aging 2018, 10, 902-929. [CrossRef] [PubMed]

189. Feng, F.; Feng, R.; Wang, M.; Zhang, J.; Jiang, H.; Jiang, Q.; Lu, J.; Liu, H.; Peng, J.; Hou, M.; et al. Articles Oral all-trans retinoic acid plus danazol versus danazol as second-line treatment in adults with primary immune thrombocytopenia: A multicentre, randomised, open-label, phase 2 trial. Lancet Haematol. 2017, 3026. [CrossRef]

190. Jaime-Pérez, J.C.; Colunga-Pedraza, P.R.; Gómez-Ramírez, C.D.; Gutiérrez-Aguirre, C.H.; Cantú-Rodríguez, O.G.; Tarín-Arzaga, L.C.; Gómez-Almaguer, D. Danazol as first-line therapy for aplastic anemia. Ann. Hematol. 2011, 90, 523-527. [CrossRef]

191. Chan, G.; DiVenuti, G.; Miller, K. Danazol for the treatment of thrombocytopenia in patients with myelodysplastic syndrome. Am. J. Hematol. 2002, 71, 166-171. [CrossRef]

192. Viniou, N.; Plata, E.; Terpos, E.; Variami, E.; Meletis, J.; Vaiopoulos, G.; Loukopoulos, D.; Chatzidimitriou, G.; Yataganas, X. Danazol therapy for thrombocytopenia in patients with myelodysplastic syndromes. Acta Haematol. 2002, 107, 234-236. [CrossRef]

193. Urhausen, A.; Torsten, A.; Wilfried, K. Reversibility of the effects on blood cells, lipids, liver function and hormones in former anabolic-androgenic steroid abusers. J. Steroid Biochem. Mol. Biol. 2003, 84, 369-375. [CrossRef]

194. Gaughan, W.J.; Liss, K.A.; Dunn, S.R.; Mangold, A.M.; Buhsmer, J.P.; Michael, B.; Burke, J.F. A 6-Month Study of Low-Dose Recombinant Human Erythropoietin Alone and in Combination with Androgens for the Treatment of Anemia in Chronic Hemodialysis Patients. Am. J. Kindy Dis. 1997, 30, 495-500. [CrossRef]

195. Koiou, E.; Tziomalos, K.; Katsikis, I.; Kalaitzakis, E.; Kandaraki, E.A.; Tsourdi, E.A.; Delkos, D.; Papadakis, E.; Panidis, D. Circulating platelet-derived microparticles are elevated in women with polycystic ovary syndrome diagnosed with the 1990 criteria and correlate with serum testosterone levels. Eur. J. Endocrinol. 2011, 63-68. [CrossRef] [PubMed]

196. Nomura, S. Critically ill Patients and Platelet-Derived Microparticles. J. Atheroscler. Thromb. 2015, 22, 752-753. [CrossRef] [PubMed]

197. Kebapcilar, L.; Taner, C.E.; Kebapcilar, A.G.; Sari, I. High mean platelet volume, low-grade systemic coagulation and fibrinolytic activation are associated with androgen and insulin levels in polycystic ovary syndrome. Arch. Gynecol. Obstet. 2009, 280, 187-193. [CrossRef] [PubMed]

198. Dogan, B.A.; Arduc, A.; Tuna, M.M.; Karakılıc, E.; Dagdelen, I.; Tutuncu, Y.; Berker, D.; Guler, S. Association of mean platelet volume with androgens and insulin resistance in nonobese patients with polycystic ovary syndrome. Int. J. Endocrinol. Metab. 2014, 12, e18642. [CrossRef] [PubMed]

199. Greenberg, S.; George, W.R.; Kadowitz, P.J.; Wilson, W.R. Androgen-induced enhancement of vascular reactivity. Can. J. Physiol. Pharmacol. 1974, 52, 14-22. [CrossRef]

200. Morikawa, M.; Kojima, T.; Inoue, M.; Tsuboi, M. Sex difference in the effect of aspirin on intracellular Ca2+ mobilization and thromboxane A2 production in rat platelets. Jpn. J. Pharmacol. 1986, 40, 463-468. [CrossRef]

201. Morinelli, T.A.; Oatis, J.E.J.; Okwu, A.K.; Mais, D.E.; Mayeux, P.R.; Masuda, A.; Knapp, D.R.; Halushka, P. V Characterization of an 125I-labeled thromboxane A2/prostaglandin H2 receptor agonist. J. Pharmacol. Exp. Ther. 1989, 251, 557-562. [PubMed] 
202. Vicencio, J.M.; Estrada, M.; Galvis, D.; Bravo, R.; Contreras, A.E.; Rotter, D.; Szabadkai, G.; Hill, J.A.; Rothermel, B.A.; Jaimovich, E.; et al. Anabolic Androgenic Steroids and Intracellular Calcium Signaling: A Mini Review on Mechanisms and Physiological Implications. Mini Rev. Med. Chem. 2011, 56, 390-398. [CrossRef]

203. Nakao, J.; Change, W.C.; Murota, S.I.; Orimo, H. Testosterone inhibits prostacyclin production by rat aortic smooth muscle cells in culture. Atherosclerosis 1981, 39, 203-209. [CrossRef]

204. Wakasugi, M.; Noguchi, T.; Kazama, Y.I.; Kanemaru, Y.; Onaya, T. The effects of sex hormones on the synthesis of prostacyclin (PGI2) by vascular tissues. Prostaglandins 1989, 37, 401-410. [CrossRef]

205. Gonzales, R.J.; Ghaffari, A.A.; Duckles, S.P.; Krause, D.N. Testosterone treatment increases thromboxane function in rat cerebral arteries. Am. J. Physiol. Heart Circ. Physiol. 2005, 289, H578-H585. [CrossRef] [PubMed] 